\title{
Experimental Performance Analysis of a Pilot-Scale Biomass- Assisted Recirculating Mixed-Flow Dryer for Drying Paddy
}

\author{
M. Yahya $\mathbb{D}^{1}{ }^{1}$ Hendriwan Fahmi, ${ }^{1}$ and R. Hasibuan ${ }^{2}$ \\ ${ }^{1}$ Fakultas Teknologi Industri, Institut Teknologi Padang, Indonesia \\ ${ }^{2}$ Departemen Teknik Kimia, Universitas Sumatera Utara, Indonesia \\ Correspondence should be addressed to M. Yahya; yahya_err@yahoo.com
}

Received 13 September 2021; Revised 31 December 2021; Accepted 3 January 2022; Published 27 January 2022

Academic Editor: Jirapornchai Suksaeree

Copyright (c) 2022 M. Yahya et al. This is an open access article distributed under the Creative Commons Attribution License, which permits unrestricted use, distribution, and reproduction in any medium, provided the original work is properly cited.

\begin{abstract}
A large amount of heat energy is required for paddy drying processes to evaporate water from paddy grains. Currently, fossil fuels are being used as an energy source to heat air during the drying process. However, fossil fuels cause air pollution, climate change, and disruption of ecological balance. In this study, to reduce the dependence on fossil fuels for paddy drying, a pilot-scale biomass-assisted recirculating mixed-flow drying system (PSBA-RMFD) for drying paddy was designed, installed, and tested. In this PSBA-RMFD, the heat energy required for heating the drying air was provided only by biomass. The PSBA-RMFD comprises a biomass furnace, drying column, vibratory feeder, bucket elevator, and blower. This study is aimed at evaluating the performance of the PSBA-RMFD with a drying capacity of $400 \mathrm{~kg} / \mathrm{h}$. The performance metrics of the PSBA-RMFD were specific energy consumption (SEC), specific thermal energy consumption (STEC), specific moisture evaporation rate (SMER), thermal efficiency of the PSBA-RMFD, exergy efficiency of the drying section, and improvement potential of the dryer. From the experiments conducted in this study, the values of the aforementioned performance parameters were as follows: $0.806-$ $8.656 \mathrm{~kW} \mathrm{~h} / \mathrm{kg}$ of water evaporated; $0.385-4.136 \mathrm{~kW} \mathrm{~h} / \mathrm{kg}$ of water evaporated; $0.122-1.308 \mathrm{~kg}$ of water evaporated $/ \mathrm{kW} \mathrm{h;} 7.82-$ 83.99\%; 15.28-25.64\%; and 858.90-1355.62 W, respectively. The paddy moisture content was reduced from $20.90 \%$ wet basis (initial weight of $400 \mathrm{~kg}$ ) to $13.30 \%$ wet basis (final weight of $364 \mathrm{~kg}$ ) in $270 \mathrm{~min}$, with an average temperature of $78.15^{\circ} \mathrm{C}$ and average relative humidity of $8.55 \%$. The percentage of biomass energy used in the drying system was approximately $47.77 \%$ of the overall energy. In addition, the payback period of the PSBA-RMFD was 1.9 years.
\end{abstract}

\section{Introduction}

Indonesia is an agricultural economy-based country with a vast agricultural land and is one of the world's leading paddy producers. Its paddy production in 2019 reached approximately 84 million $t$. Indonesia is also one of the world's largest paddy consumers, with an annual per capita consumption of approximately $111.58 \mathrm{~kg}$ [1]. In Indonesia, the paddy after being harvested must be dried immediately to avoid mold growth and yellowing of grains, as Indonesia's climate is characterized by high humidity. The harvested paddy contains a high degree of moisture, ranging from $20 \%$ to $27 \%$ (wet basis). Therefore, to secure a long shelf life, the paddy is typically dried to a moisture content of $14 \%$ (wet basis) [2]. Traditionally, paddy is dried using open sun drying, where the product is exposed directly to the sun. Drying with open sunlight has several advantages, including free and abundant supply of energy from the sun, simplicity of the method, and low initial and maintenance costs; however, its disadvantages include, the requirement of a large area, which is a function of the solar radiation, long drying times, lowered quality of the dried products, and significant loss of paddy during the drying process.

To overcome the limitations of open sun drying for drying paddy, a mixed-flow dryer can be used, which offers significant advantages, such as suitability for drying of grains, short drying time, good quality of the dried products, and smaller losses in the quantity of paddy during the drying process [3].

Mixed-flow dryers have been used to dry high-moisture grain products, such as rice [4], maize [5], wheat [6-11], soybeans [12, 13], barley, oats [14], and corn [15]. However, fossil fuels are still being used as energy sources for heating 
the drying air during the drying process. Fossil fuels suffer from disadvantages, such as generation of significant amounts of $\mathrm{CO}_{2}, \mathrm{SO}_{2}$, and Nox emissions. They cause air pollution, climate change, and disruption of ecological balance. Moreover, their prices are high and will continue to rise, while their resources are limited $[16,17]$.

Biomass energy serves as an alternative to fossil fuels and has some advantages, such as low emissions and sustainable renewable energy sources. Moreover, it is locally available in abundance and is relatively low-priced.

A few researchers have developed various drying systems using biomass energy sources to dry diverse products, for example, integrating the drying system with a biomass furnace (biomass burner); using fluidized bed dryers to dry paddy $[17,18]$, convective tray dryers to dry plantain slices [19], maize [20], candle nuts [21], red chili [22], natural rubber sheet [23], cashew kernel [24], food and fish [25], chili [26], pineapple [27], ginger, turmeric guduchi [28], and pineapple; and using tunnel dryers to dry fish [29] and green pepper [30].

Paddy drying process consumes a large amount of heat energy to evaporate water in the paddy grains [31]. Several researchers have conducted performance analyses in terms of energy consumption (specific energy) for different types of dryers for paddy drying; these include among others, fixed bed dryers [32], fixed deep bed dryers [33], inclined bed dryers [34], fluidized bed dryers [17, 18, 35-43], spouted bed dryers [40, 44], crossflow dryers [45, 46], mixed-flow dryers [47], recirculating grain dryers [48], rotary dryers $[32,49]$, impinging stream dryers [50], and combined impinging stream and pneumatic dryers [51]. The energy consumption of various dryers used for paddy drying is summarized in Table 1.

However, to the best of our knowledge, the performance of a pilot-scale biomass-assisted recirculating mixed-flow dryer (PSBA-RMFD) for drying paddy using biomass energy as a source of heat energy has not yet been reported. In addition, Indonesia produces significantly large amounts of biomass energy every year (approximately 236 million $t$; 756.083 million GJ), and this can be used as a source of heat energy in the drying process [52]. Therefore, this study is aimed at designing, installing, and evaluating the performance of a PSBA-RMFD for drying paddy using biomass as a source of heat energy.

\section{Materials and Methods}

2.1. Experimental Set-Up. A PSBA-RMFD, which comprised a biomass furnace, drying column, vibratory feeder, bucket elevator, and blower, was designed and installed. Photographs and a schematic of the PSBA-RMFD are presented in Figures 1 and 2. The biomass furnace consisted of the following key parts: a furnace chamber, heat exchanger pipes, chimney, and blower. The wall of the furnace chamber was fabricated from Sk-34 fire brick, Sk-34 cement mortar, and AISI 1030 steel plate materials. Sk-34 fire brick has advantages such as high mechanical strenght, high temperature resistance, and high resistance to abrasion; Sk-34 cement mortar has advantages such as high temperature resistance and high adhesiveness. Meanwhile, AISI 1030 steel plate has advantages such as high mechanical strenght and high temperature resistance. The pipes of the heat exchanger were fabricated from mild steel. The drying column had three main sections, namely, the storage, drying, and discharge sections, and its dimensions are shown in Figure 3. The discharge section consisted of a motor, gear box, sprocket, chain, roller, and support structure. The vibratory feeder consisted of a motor, pulley, bearing, trough, and support structure. The bucket elevator consisted of a pulley, belt, buckets, gear box, motor, feed hopper, discharge sprout, and casing. The drying section of the drying column had a cross-sectional area of $95 \times 95 \mathrm{~cm}^{2}$ and was equipped with inlet and outlet air ducts arranged horizontally. The inlet and outlet air ducts consisted of four rows each. Each inlet air duct row had six full-air ducts, and each outlet air duct row had five full and two half-air ducts. The crosssectional area of each air duct was $56.25 \mathrm{~cm}^{2}$. The inlet and outlet air ducts were wedge-shaped. The photographs of air duct and drying section are shown in Figure 4. Meanwhile, the arrangement of air ducts and their dimensions (in the drying section) are shown in Figures 5 and 6.

The working procedure of the PSBA-RMFD is presented in Figure 2. At first, the dryer is filled with moist paddy by a bucket elevator into the hopper at top the dryer and flowed vertically downwards by gravity, while the discharge roller at the bottom of the dryer is turned off (discharge device is closed). The discharge roller operated on the principle of a rotary valve to allow a constant product mass flow rate. When the moist paddy in the dryer reach the desired height, then the ambient air is passed through the biomass furnace heat exchanger by a centrifugal blower to increase its temperature. The ambient air is heated up to a prescribed temperature with the heat generated by burning the biomass fuel (coconut shell charcoal) in the combustion chamber of the biomass furnace. Then, the heated air is passed to the drying section, from where the heated air is forced through the paddy grains outwards carrying the moisture from drying material. Then, the moist air is discharged into the environment. In the drying section, the moist grains crosses the drying section nearly vertically while heated air (drying air) flows horizontally. Then, the discharge roller is turned on (discharge device is opened). Subsequently, the dried paddy falls into the vibratory feeder, then flow to the bottom of the bucket elevator. From here, the dried paddy is moved or circulated to the top of dryer by the bucket elevator for further drying process. This process continues until the desired moisture content of the paddy grains is achieved.

2.2. Experimental Procedure. A drying experiment was conducted to evaluate the performance of the PSBA-RMFD, with a holding capacity of $400 \mathrm{~kg}$. Fresh paddy was purchased from a farmer, and during the drying experiment the ambient temperature, the air temperatures at the entry and exit of the biomass furnace, drying section, and the temperatures of the paddy at various points inside the drying section were measured using thermocouples (type $\mathrm{T}$, accuracy: $\pm 0.1^{\circ} \mathrm{C}$, operating range: -200 to $400^{\circ} \mathrm{C}$, Japan). An anemometer (model HT383, accuracy: $\pm 0.2 \mathrm{~ms}^{-1}$, operating 
TABLE 1: Summary of energy consumption of various types of dryers for paddy drying (from the literature).

\begin{tabular}{|c|c|c|c|c|c|c|c|c|}
\hline \multirow{2}{*}{ No. } & \multirow{2}{*}{ Type of dryer } & \multirow{2}{*}{$\begin{array}{l}\text { Temperature } \\
\left({ }^{\circ} \mathrm{C}\right)\end{array}$} & \multicolumn{2}{|c|}{$\begin{array}{l}\text { Moisture content (\%) } \\
\text { wb }\end{array}$} & \multirow{2}{*}{$\begin{array}{l}\text { SEEC }(\mathrm{MJ} / \mathrm{kg} \text { of } \\
\text { water evaporated) }\end{array}$} & \multirow{2}{*}{$\begin{array}{l}\text { STEC }(\mathrm{MJ} / \mathrm{kg} \text { of } \\
\text { water evaporated) }\end{array}$} & \multirow{2}{*}{$\begin{array}{c}\mathrm{SEC}(\mathrm{MJ} / \mathrm{kg} \text { of } \\
\text { water evaporated) }\end{array}$} & \multirow{2}{*}{ Reference } \\
\hline & & & Initial & Final & & & & \\
\hline 1 & $\begin{array}{l}\text { Pilot-scale fluidized bed } \\
\text { dryer, feed rate } 1.0 \mathrm{t} / \mathrm{h}\end{array}$ & $100-120$ & $30-32$ & $19-19.7$ & - & - & $1.587-2.418$ & [35] \\
\hline 2 & $\begin{array}{l}\text { Fluidized bed dryer, } \\
\text { capacity (feed rate) } 0.82 \text { ton } / \mathrm{h}\end{array}$ & $100-120$ & $45(\mathrm{db})$ & $24(\mathrm{db})$ & 0.53 & 1.79 & - & {$[36]$} \\
\hline 3 & $\begin{array}{l}\text { Industrial-scale fluidized } \\
\text { bed dryer, feed rate } 2.5-4.0 \mathrm{t} / \mathrm{h}\end{array}$ & 144 & 25 & 20 & - & - & 4.2 & [37] \\
\hline 4 & $\begin{array}{l}\text { Laboratory scale spouted } \\
\text { bed dryer, feed rate } 1000 \mathrm{~kg} / \mathrm{h}\end{array}$ & 144 & $20(\mathrm{db})$ & $14.4(\mathrm{db})$ & 0.76 & 6.7 & - & {$[44]$} \\
\hline 5 & $\begin{array}{l}\text { Industrial-scale fluidized bed } \\
\text { dryer, feed rate } 2.3-7.9 \mathrm{t} / \mathrm{h}\end{array}$ & 150 & $18-21.1$ & $15.3-15.5$ & - & - & $5.36-6.89$ & {$[38]$} \\
\hline 6 & Fluidized bed dryer & $100-110$ & $21-23.6$ & $10.4-13.6$ & - & - & $3.874-4.421$ & [39] \\
\hline 7 & $\begin{array}{l}\text { Combined impinging stream } \\
\text { and pneumatic drying system, mass } \\
\text { flow rate (feed rate) } 22 \mathrm{~kg}_{\text {dry solid }} / \mathrm{h}\end{array}$ & 70 & 28 & 21.4 & 2.2 & 0.9 & 3.1 & {$[51]$} \\
\hline 8 & $\begin{array}{l}\text { Impinging stream dryer, particle flow } \\
\text { rate (feed rate) } 150 \mathrm{~kg}_{\text {dry solid }} / \mathrm{h}\end{array}$ & 110 & $28(\mathrm{db})$ & $21.7(\mathrm{db})$ & - & - & 5.1 & {$[50]$} \\
\hline \multirow{2}{*}{9} & Fluidized bed dryer & 80 & 20 & 14 & - & - & 30.9 & \multirow{2}{*}[40]{} \\
\hline & Spouted bed dryer & 80 & 20 & 14 & - & - & 11.7 & \\
\hline 10 & $\begin{array}{l}\text { Industrial inclined bed dryer, } \\
\text { holding capacity } 15 \mathrm{t}\end{array}$ & $41-42$ & $22-23$ & 12.5 & $1.44-195$ & $2.77-3.47$ & - & {$[34]$} \\
\hline 11 & $\begin{array}{l}\text { Industrial fluidized bed dryer, } \\
\text { capacity (feed rate) } 7.75 \mathrm{t} / \mathrm{h}\end{array}$ & $100-120$ & $36.98(\mathrm{db})$ & $27.58(\mathrm{db})$ & 0.79 & 7.57 & - & [41] \\
\hline 12 & $\begin{array}{l}\text { Fully automated pilot-scale } \\
\text { model fluidized bed dryer, } \\
\text { feed rate } 500 \mathrm{~kg} / \mathrm{h}\end{array}$ & 70 & 28 & 14.1 & - & - & 2.84 & {$[42]$} \\
\hline 13 & $\begin{array}{l}\text { Horizontal rotary dryer, } \\
\text { holding capacity } 3 \mathrm{t}\end{array}$ & $38-40$ & 14.5 & 8 & $5.50-17.41$ & $11.5-36.44$ & - & [49] \\
\hline 14 & $\begin{array}{l}\text { Fluidized bed dryer (vertical), } \\
\text { holding capacity } 12 \mathrm{~kg}\end{array}$ & 78 & 20 & 14 & - & - & $\begin{array}{l}2.27-7.69 \mathrm{~kW} \mathrm{~h} / \\
\mathrm{kg}\end{array}$ & {$[17]$} \\
\hline 15 & Fixed deep bed dryer & 80 & 20.4 & 12 & - & - & $\begin{array}{c}1.891-12.014 \mathrm{~kW} \\
\mathrm{~h} / \mathrm{kg}\end{array}$ & {$[33]$} \\
\hline 16 & $\begin{array}{l}\text { Small scale mixed-flow dryer, } \\
\text { holding capacity } 30 \mathrm{~kg}\end{array}$ & 45 & 25 & 12 & 0.97 & 3.17 & - & {$[47]$} \\
\hline 17 & $\begin{array}{l}\text { Industrial recirculating grain dryer, } \\
\text { holding capacity } 30 \mathrm{t}\end{array}$ & 60 & 30 & 14 & $19.2 \mathrm{~kW} \mathrm{h/t}$ & $371.9 \mathrm{MJ} / \mathrm{t}$ & - & {$[48]$} \\
\hline 18 & $\begin{array}{l}\text { Fluidized bed dryer (horizontal), } \\
\text { holding capacity } 11 \mathrm{~kg}\end{array}$ & 59.58 & 20 & 14 & $1.960 \mathrm{~kW} \mathrm{h/kg}$ & $1.532 \mathrm{~kW} \mathrm{h/kg}$ & $3.528 \mathrm{~kW} \mathrm{h/kg}$ & {$[18]$} \\
\hline 19 & Crossflow dryer, feed rate $60 \mathrm{~kg} / \mathrm{h}$ & 130 & 20.6 & 14 & - & - & 5.85 & {$[45]$} \\
\hline 20 & $\begin{array}{l}\text { Continuous crossflow dryer, } \\
\text { feed rate } 36 \mathrm{~kg} / \mathrm{h}\end{array}$ & 150 & 20 & 14.3 & - & - & 3.6 & {$[46]$} \\
\hline 21 & $\begin{array}{l}\text { Solar-assisted fluidized bed dryer } \\
\text { (vertical), holding capacity } 0.5 \mathrm{~kg}\end{array}$ & 45 & 21 & 10 & - & - & $\begin{array}{l}8.30-22.12 \mathrm{~kW} \mathrm{~h} / \\
\mathrm{kg}\end{array}$ & {$[43]$} \\
\hline \multirow{2}{*}{22} & $\begin{array}{l}\text { Rotary dryer, holding capacity } \\
\qquad 3000 \mathrm{~kg}\end{array}$ & $35-40$ & 12 & 8 & - & - & 10.48 & \multirow{2}{*}[32]{} \\
\hline & $\begin{array}{l}\text { Fixed bed dryer, holding } \\
\text { capacity } 3000 \mathrm{~kg}\end{array}$ & $30-40$ & 12 & 7.6 & - & - & 9.81 & \\
\hline
\end{tabular}

SEEC: specific electrical energy consumption; STEC: specific thermal energy consumption; SEC: specific energy consumption; db: dry basis; Wb: wet basis.

range: $0-30 \mathrm{~ms}^{-1}$, China) was used to measure the air velocity at the inlet and outlet of the drying section. The ambient temperature, air temperature, and temperature of the paddy were recorded using a data logger (model AH4000, accuracy: $\pm 0.1^{\circ} \mathrm{C}$, channel 12, Japan). A grain moisture tester (type digital, model OEM MC-7828G, accuracy: $\pm 0.5 \%$, measuring range: $\pm 0 \%-50 \%$, China) was used to measure the change in the moisture content of the paddy. The mass of biomass fuel (coconut shell charcoal) was weighed using a weighing scale (model TKB-0.15, accuracy: $\pm 0.05 \mathrm{~kg}$, measuring range: 0 $15 \mathrm{~kg}$, China). The mass of the paddy was weighed using a weighing scale (model Camry, accuracy: $\pm 0.1 \mathrm{~kg}$, measuring range: $0-100 \mathrm{~kg}$, China). The ambient temperature, air temperatures, temperature of the paddy, and moisture content 


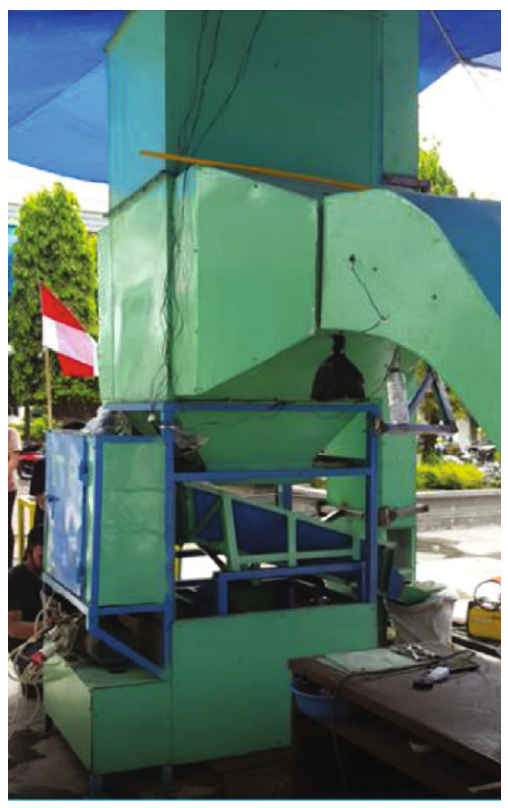

(a)

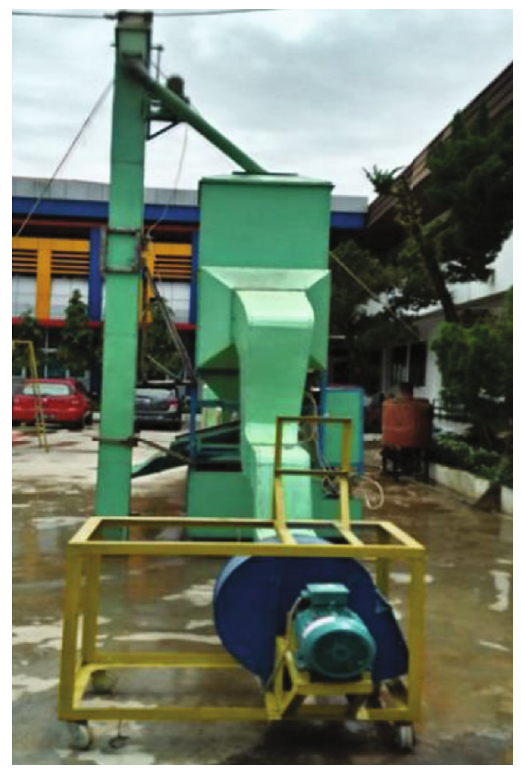

(c)

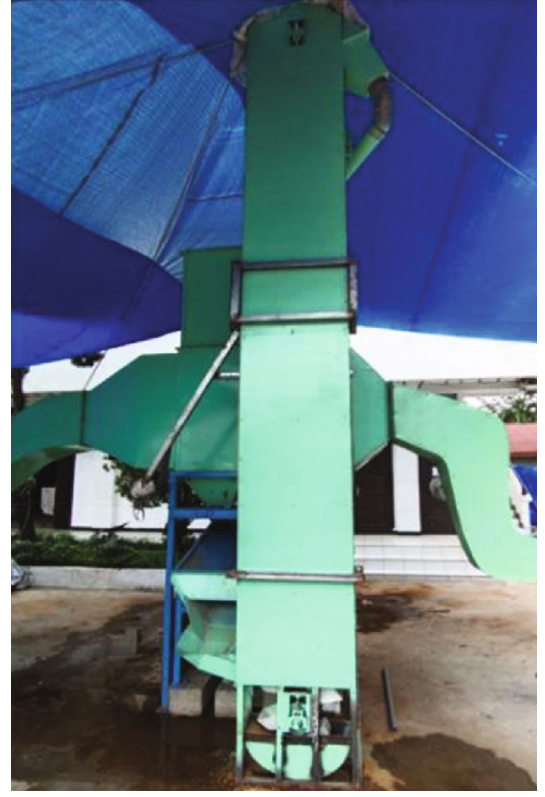

(b)

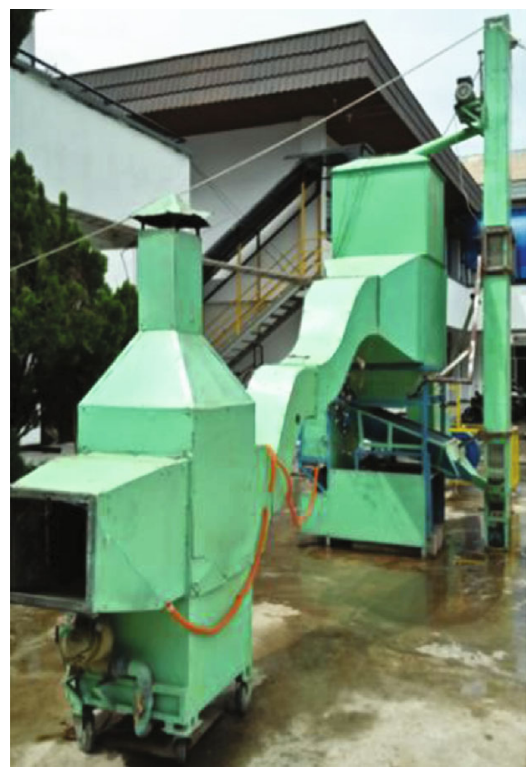

(d)

Figure 1: Photograph of the PSBA-RMFD: (a) front view, (b) back view, (c) left view, and (d) right view.

of the paddy were recorded every $30 \mathrm{~min}$. The uncertainty of measurements was determined using the following equation $[53,54]$ :

$$
W_{r}=\left[\left(\frac{\partial R}{\partial x_{1}} w_{1}\right)^{2}+\left(\frac{\partial R}{\partial x_{2}} w_{2}\right)^{2}+\cdots+\left(\frac{\partial R}{\partial x_{n}} w_{n}\right)^{2}\right]^{1 / 2}
$$

where $W_{R}$ is the total uncertainty in the result measurement; $x_{1}, x_{2}, \cdots x_{n}$ are the independent variables; and $w_{1}$, $w_{2}, \cdots w_{n}$ are the corresponding uncertainties in the aforementioned independent variables.
2.3. Performance Analysis. The performance of the PSBARMFD, in terms of the drying rate $\left(\dot{m}_{\text {water }}\right)$, specific energy consumption (SEC), specific thermal energy consumption (STEC), specific electrical energy consumption (SEEC), specific moisture evaporation rate (SMER), thermal efficiency of the dryer $\left(\eta_{\mathrm{th}}\right)$, exergy efficiency of the drying sections $\left(\eta_{\mathrm{Ex}}\right)$, improvement potential (IP), and efficiency of the biomass furnace $\left(\eta_{\mathrm{BF}}\right)$ was determined using the equations presented in Table 2. The data obtained from the performance analysis of the PSBA-RMFD during the drying experiment of the paddy are presented in Table 3 . 


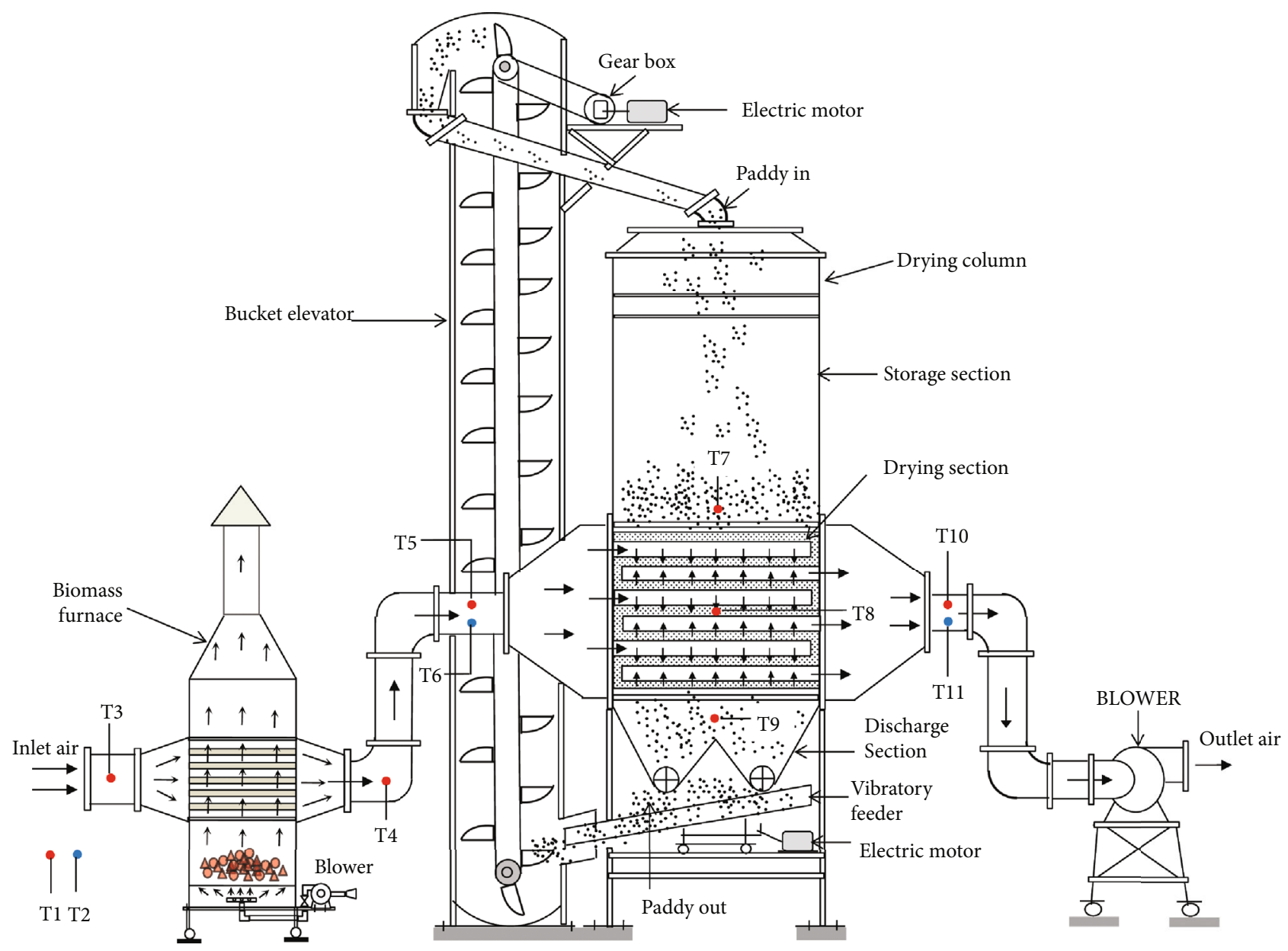

FIgURE 2: Schematic of the PSBA-RMFD.

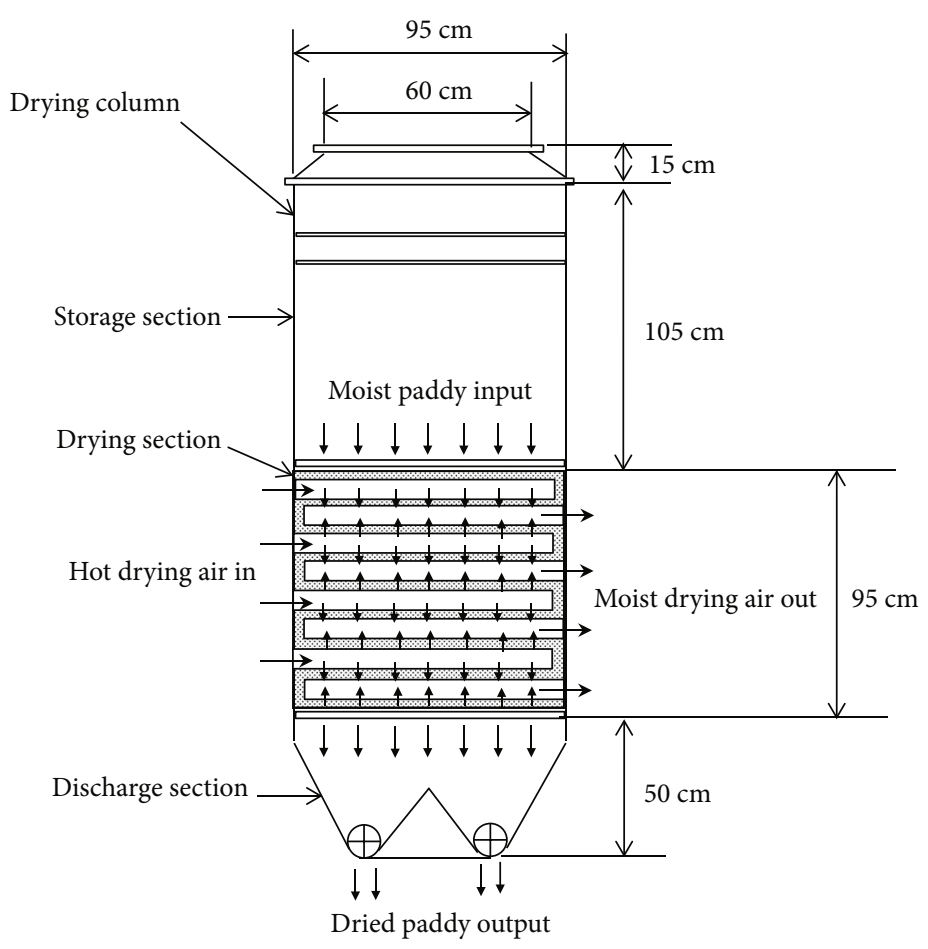

FIGURE 3: Schematic of the drying column with dimensions. 


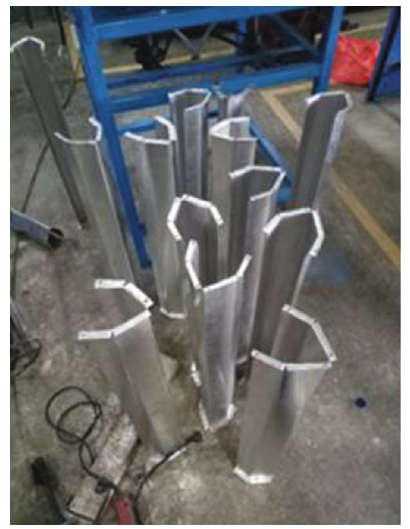

(a)

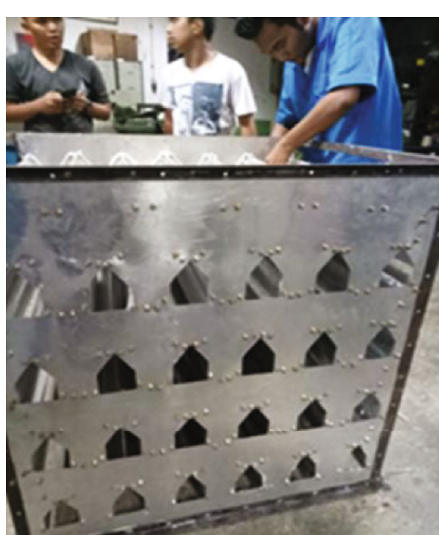

(b)

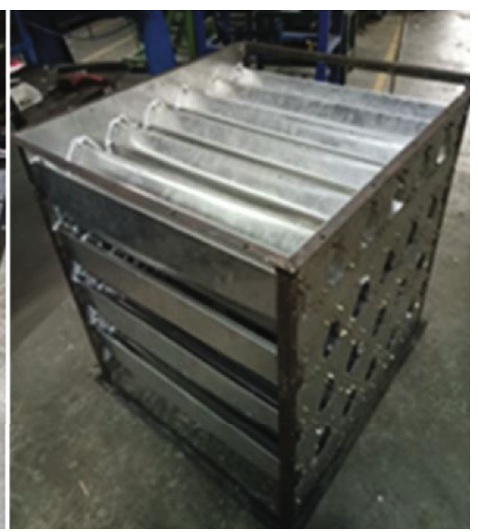

Figure 4: (a) Photograph of the air duct. (b) Photograph of the drying section.

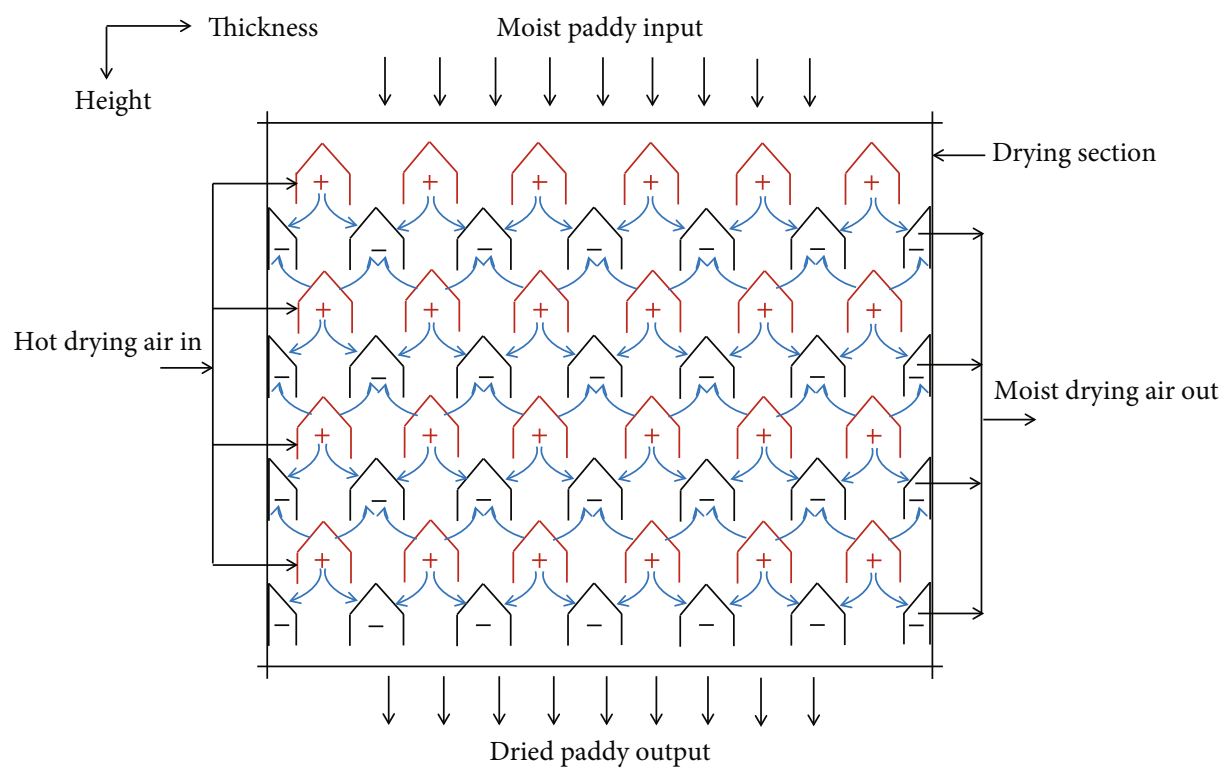

FIGURE 5: Air duct arrangement in the drying section (+ hot air inlet; - moist air outlet).

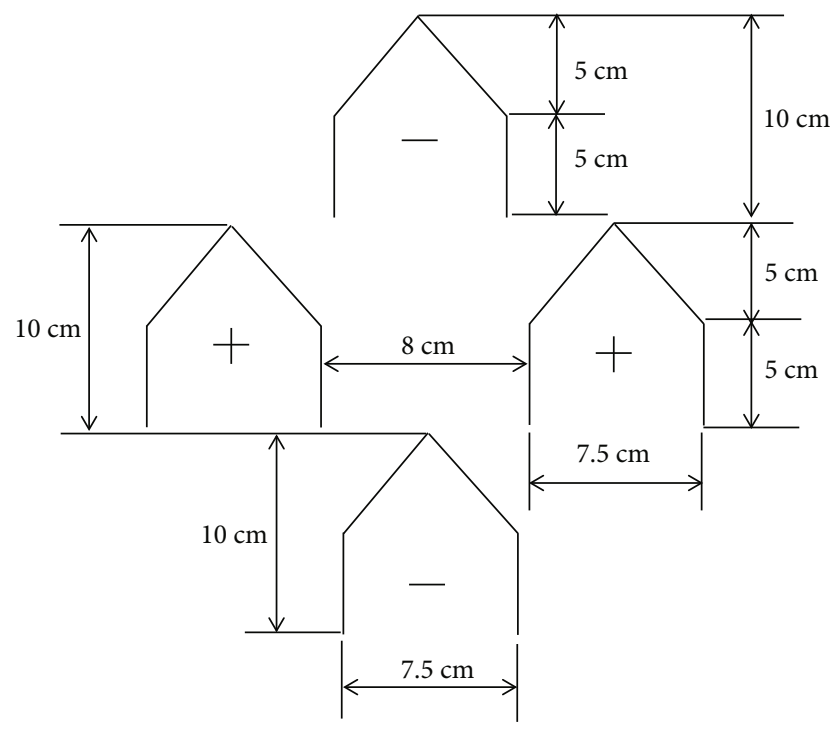

FIGURE 6: Schematic of the air ducts with dimensions.
2.4. Economic Analysis. For evaluating the economy of a drying system, two important aspects should be considered: first, the investment cost $\left(I_{C}\right)$; second, the production cost $\left(C_{\mathrm{pr}}\right)$, profit $(\mathrm{PR})$, return on capital (ROC), payback period (PP), and net present value (NPV). $I_{C}$ of the PSBA-RMFD includes the costs of the biomass furnace, drying column, vibratory feeder, bucket elevator, air duct, motor, blower, and labor for construction and installation. The components of $I_{C}$ are listed in Table $4 . C_{\mathrm{pr}}$, PR, ROC, PP, and NPV of the PSBA-RMFD were calculated using the equations presented in Table 5.

\section{Results and Discussion}

3.1. Performance Evaluation. Table 6 summarizes the uncertainties in the parameters during the paddy drying experiment. Referring to Table 3, the ambient temperature (T1) and ambient relative humidity ranged between 30.30 and $35.60^{\circ} \mathrm{C}$ and $50.76 \%$ to $65.37 \%$, respectively, with 
TABLE 2: Equations used to determine the performance of the PSBA-RMFD.

\begin{tabular}{|c|c|c|c|}
\hline Performance indicator & Equation & $\begin{array}{l}\text { Eq. } \\
\text { no. }\end{array}$ & Ref. \\
\hline Specific energy consumption & $\overline{\mathrm{SEC}}=E_{\mathrm{bmf}}+E_{\mathrm{Bbf}}+E_{\mathrm{Mdr}}+E_{\mathrm{Mbe}}+E_{\mathrm{Mvf}}+E_{\mathrm{Bmfd}} / \dot{m}_{\text {water }}$ & $(2)$ & {$[43]$} \\
\hline Specific thermal energy consumption & $\mathrm{STEC}=E_{\mathrm{bmf}} / \dot{m}_{\text {water }}$ & (3) & $\begin{array}{l}{[18,} \\
34]\end{array}$ \\
\hline Specific electrical energy consumption & $\mathrm{SEEC}=E_{\mathrm{Bbf}}+E_{\mathrm{Mdr}}+E_{\mathrm{Mbe}}+E_{\mathrm{Mvf}}+E_{\mathrm{Bmfd}} / \dot{m}_{\text {water }}$ & $(4)$ & $\begin{array}{l}{[18,} \\
34]\end{array}$ \\
\hline Specific moisture evaporation rate & $\mathrm{SMER}=\dot{m}_{\mathrm{water}} / E_{\mathrm{bmf}}+E_{\mathrm{Bbf}}+E_{\mathrm{Mdr}}+E_{\mathrm{Mbe}}+E_{\mathrm{Mvf}}+E_{\mathrm{Bmfd}}$ & $(5)$ & {$[55]$} \\
\hline Drying rate & $\dot{m}_{\text {water }}=M_{\mathrm{Cdb}, t+\Delta \mathrm{t}}-M_{\mathrm{Cdb}, t} / \Delta t$ & $(6)$ & {$[54]$} \\
\hline Paddy moisture content (wet basis) & $M_{\text {Cwb }}=m_{\text {wetpd }}-m_{\text {bonedrypd }} / m_{\text {wetpd }}$ & $(7)$ & [54] \\
\hline Paddy moisture content (dry basis) & $M_{\mathrm{Cdb}}=m_{\text {wetpd }}-m_{\text {bonedrypd }} / m_{\text {bonedrypd }}$ & $(8)$ & {$[54]$} \\
\hline Moisture ratio & $\mathrm{MR}=\mathrm{Mt} / \mathrm{Mo}$ & $(9)$ & [43] \\
\hline $\begin{array}{l}\text { Electrical energies required by blower of biomass furnace, motor of } \\
\text { bucket elevator, and motor of vibratory feeder }\end{array}$ & $E_{\mathrm{Bbf}}, E_{\mathrm{Mbe}}$, and $E_{\mathrm{Mvf}}=\mathrm{VI} \cos \phi$ & (10) & [22] \\
\hline $\begin{array}{l}\text { Electrical energies required by the motor of discharge roller and } \\
\text { blower of mixed-flow dryer }\end{array}$ & $E_{\mathrm{Mdr}}$ and $E_{\mathrm{Bmfd}}=\sqrt{3} \mathrm{VI} \cos \phi$ & (11) & {$[17]$} \\
\hline Dryer thermal efficiency & $\eta_{\mathrm{th}}=\dot{m}_{\mathrm{water}} H_{\mathrm{fg}} / E_{\mathrm{bmf}}+E_{\mathrm{Bbf}}+E_{\mathrm{Mbe}}+E_{\mathrm{Mvf}}+E_{\mathrm{Bmfd}}$ & $(12)$ & [47] \\
\hline Exergy inflow & $\mathrm{EX}_{i, \mathrm{ds}}=\dot{m}_{a} C_{\mathrm{Pa}}\left[\left(T_{\mathrm{aid}, \mathrm{ds}}-T_{\mathrm{amb}}\right)-T_{\mathrm{amb}} \ln \left(T_{\mathrm{aid}, \mathrm{ds}} / T_{\mathrm{amb}}\right)\right]$ & (13) & $\begin{array}{l}{[17,} \\
53]\end{array}$ \\
\hline Exergy outflow & $\mathrm{EX}_{o, \mathrm{ds}}=\dot{m}_{a} C_{\mathrm{Pa}}\left[\left(T_{\mathrm{ao}, \mathrm{ds}}-T_{\mathrm{amb}}\right)-T_{\mathrm{amb}} \ln \left(T_{\mathrm{ao}, \mathrm{ds}} / T_{\mathrm{amb}}\right)\right]$ & (14) & $\begin{array}{l}{[17,} \\
53]\end{array}$ \\
\hline Exergy losses & $\mathrm{EX}_{\text {loss }}=\mathrm{EX}_{i, \mathrm{ds}}-\mathrm{EX}_{o, \mathrm{ds}}$ & (15) & $\begin{array}{l}{[17,} \\
53]\end{array}$ \\
\hline Exergy efficiency of drying section & $\eta_{\mathrm{Ex}}=\mathrm{EX}_{o, \mathrm{ds}} / \mathrm{EX}_{i, \mathrm{ds}}=1-\mathrm{EX}_{\mathrm{loss}} / \mathrm{EX}_{i, \mathrm{ds}}$ & (16) & $\begin{array}{l}{[17,} \\
53]\end{array}$ \\
\hline Improvement potential & $\mathrm{IP}=\left(1-\eta_{\mathrm{Ex}}\right) \mathrm{EX}_{\text {loss }}$ & (17) & {$[54]$} \\
\hline Efficiency of biomass furnace & $\eta_{\mathrm{BF}}=\left(E_{\mathrm{Ubf}} / E_{\mathrm{bmf}}\right) x 100 \%$ & (18) & {$[22]$} \\
\hline Heat energy produced from burning of biomass fuel & $E_{\mathrm{bmf}}=\dot{m}_{\mathrm{bmf}} \mathrm{CV}_{\mathrm{bmf}}$ & (19) & {$[22]$} \\
\hline Useful heat from biomass furnace & $E_{\mathrm{Ubf}}=\dot{m}_{\mathrm{a}} C_{\mathrm{Pa}}\left(T_{\mathrm{ao}, \mathrm{bf}}-T_{\mathrm{ai}, \mathrm{bf}}\right)$ & $(20)$ & [22] \\
\hline
\end{tabular}

TABLE 3: Data from the drying experiment, used for the performance analysis of the PSBA-RMFD.

\begin{tabular}{|c|c|c|c|c|c|c|c|c|c|c|c|c|c|c|c|}
\hline \multirow{2}{*}{$\begin{array}{l}\text { Time } \\
(\min )\end{array}$} & \multirow{2}{*}{$\begin{array}{l}\text { Moisture content (\%,wet } \\
\text { basis) }\end{array}$} & \multicolumn{11}{|c|}{ Temperature $\left({ }^{\circ} \mathrm{C}\right)$} & \multicolumn{3}{|c|}{$\begin{array}{c}\text { Relative humidity } \\
(\%)\end{array}$} \\
\hline & & $\mathrm{T} 1$ & $\mathrm{~T} 2$ & T3 & $\mathrm{T} 4$ & T5 & T6 & T7 & $\mathrm{T} 8$ & T9 & $\mathrm{T} 10$ & $\mathrm{~T} 11$ & $\mathrm{Rh}_{\mathrm{amb}}$ & $\mathrm{Rh}_{i, \mathrm{ds}}$ & $\mathrm{Rh}_{o, \mathrm{ds}}$ \\
\hline 0 & 20.90 & 30.30 & 25.00 & 30.60 & 79.50 & 77.50 & 35.50 & 46.30 & 37.50 & 34.90 & 40.40 & 34.10 & 65.37 & 7.22 & 57.45 \\
\hline 30 & 19.50 & 31.40 & 25.50 & 30.70 & 80.70 & 77.80 & 38.20 & 48.20 & 38.20 & 36.40 & 40.70 & 35.10 & 62.63 & 9.64 & 53.72 \\
\hline 60 & 17.60 & 34.20 & 26.10 & 31.70 & 85.80 & 80.40 & 36.40 & 49.30 & 38.60 & 36.50 & 42.20 & 39.60 & 53.04 & 6.77 & 51.69 \\
\hline 90 & 15.90 & 34.70 & 27.20 & 32.60 & 80.80 & 75.40 & 36.30 & 49.20 & 39.00 & 35.20 & 44.10 & 39.80 & 56.39 & 9.02 & 53.49 \\
\hline 120 & 14.90 & 34.40 & 25.80 & 35.50 & 86.30 & 78.60 & 38.30 & 49.60 & 38.90 & 37.20 & 46.70 & 39.70 & 50.76 & 9.31 & 51.85 \\
\hline 150 & 14.40 & 32.50 & 25.40 & 33.50 & 86.80 & 81.40 & 37.80 & 49.90 & 39.30 & 38.50 & 45.60 & 38.90 & 56.86 & 7.53 & 52.38 \\
\hline 180 & 13.90 & 33.50 & 25.90 & 33.10 & 78.20 & 76.30 & 35.70 & 51.00 & 39.40 & 39.90 & 45.30 & 39.70 & 55.01 & 7.97 & 49.41 \\
\hline 210 & 13.70 & 33.40 & 25.70 & 31.50 & 81.70 & 77.00 & 37.70 & 51.30 & 39.50 & 40.90 & 44.20 & 40.30 & 54.43 & 9.57 & 48.88 \\
\hline 240 & 13.50 & 34.70 & 26.40 & 32.90 & 88.90 & 78.40 & 38.10 & 51.90 & 38.80 & 41.00 & 46.50 & 38.50 & 52.45 & 9.22 & 44.89 \\
\hline 270 & 13.30 & 35.60 & 27.30 & 33.20 & 86.40 & 78.70 & 38.30 & 54.70 & 39.40 & 41.70 & 48.40 & 40.10 & 53.13 & 9.26 & 39.75 \\
\hline
\end{tabular}

$\mathrm{Rh}_{\mathrm{amb}}$ : ambient relative humidity; $\mathrm{Rh}_{\mathrm{i}, \mathrm{ds}}:$ relative humidity entering the drying section; $\mathrm{Rh}_{\mathrm{ods}}:$ relative humidity leaving the drying section. 
TABLE 4: Investment cost of the PSBA-RMFD.

\begin{tabular}{lc}
\hline Item & USD \\
\hline Biomass furnace & 314.75 \\
Drying column & 649.09 \\
Bucket elevator & 669.02 \\
Vibratory feeder & 220.67 \\
Air duct & 174.86 \\
Blower & 909.28 \\
Labor for construction and installation & 909.28 \\
Total & $3,846.95$ \\
\hline
\end{tabular}

corresponding average values of $33.47^{\circ} \mathrm{C}$ and $56.01 \%$. The ambient temperature affects the ambient relative humidity; for example, a high ambient temperature results in a low ambient relative humidity and vice versa.

The efficiency of the biomass furnace as well as the temperatures of air entering and leaving the biomass furnace with time is presented in Figure 7. These temperatures varied over $30.60-35.50^{\circ} \mathrm{C}$ and $78.20-88.90^{\circ} \mathrm{C}$, with average values of 32.73 and $83.51^{\circ} \mathrm{C}$, respectively. The efficiency of biomass furnace is the ratio of the extraction of heat energy from biomass furnace or heat energy used for drying process to the heat energy produced from burning of biomass fuel, and it was calculated using Eq. (18). The efficiency of the biomass furnace was found to be $70.63-87.70 \%$, with an average value of $79.53 \%$ and an air mass flow rate of $0.1084 \mathrm{kgs}^{-1}$.

The air temperature and relative humidity values of air entering and leaving the drying section with the drying time are presented in Figure 8. The temperatures of air entering and leaving the drying section were in the ranges of 75.40$81.40^{\circ} \mathrm{C}$ and $46.30-54.70^{\circ} \mathrm{C}$, respectively, with corresponding average values of $78.15^{\circ} \mathrm{C}$ and $50.14^{\circ} \mathrm{C}$. The relative humidity values of air entering and leaving the drying section were in the ranges of $6.77 \%-9.57 \%$ and $39.75 \%-57.45 \%$, with corresponding average values of $8.55 \%$ and $50.35 \%$. As shown in Figure 8 , the air temperature value leaving the drying section increased with increasing in drying time, while the air relative humidity value decreased with increasing in drying time.

These, due to the heat and mass transfer coefficients, decreased with increasing in the drying time.

The paddy temperatures at the inlet, center, and outlet of the drying section with the drying time are illustrated in Figure 9. These temperatures varied from 34.90 to $41.70^{\circ} \mathrm{C}$, 40.40 to $48.40^{\circ} \mathrm{C}$, and 34.10 to $40.30^{\circ} \mathrm{C}$, respectively, with corresponding average values of $38.22,44.41$, and $38.58^{\circ} \mathrm{C}$. As shown in Figure 9, the paddy temperature at the center of the drying section was observed to be higher than the paddy temperatures at the inlet and outlet of the drying section due to high heat transfer rate in the drying section.

The variation in the paddy moisture content and drying rate with the drying time is presented in Figure 10. The paddy moisture content inside the drying section was reduced from $20.90 \%$ wet basis (initial weight $400 \mathrm{~kg}$ ) to $13.30 \%$ wet basis (final weight $364 \mathrm{~kg}$ ) in $270 \mathrm{~min}$, for a mass flow rate of $0.1084 \mathrm{~kg} / \mathrm{s}$, average temperature of $78.15^{\circ} \mathrm{C}$, and average relative humidity of $8.55 \%$. The drying rate is defined as the mass of moisture removed from the product per unit time and it was estimated using Eq. (6). The drying rate was found to be $1.688-18.126 \mathrm{~kg} / \mathrm{h}$, with an average of $7.792 \mathrm{~kg} / \mathrm{h}$. As shown in Figure 10, paddy drying occurred in the falling rate period, and constant drying rate period was not observed. In the falling rate period, the material surface is no longer saturated with water, and the drying rate is controlled by diffusion of moisture from the interior of solid to the surface. During the falling rate period, the drying rate decreased with increasing in drying time, and this is due to the decreased mass transfer rate with increasing in drying time.

The variation of the moisture ratio (MR) with the drying time is illustrated in Figure 11. It is defined as the ratio of the initial moisture content of paddy to the instantaneous moisture content of paddy during the drying process, and it was calculated using Eq. (9). The moisture ratio of paddy in PSBA-RMFD decreased exponentially with increasing drying time. The continuous decrease in the moisture ratio indicates that diffusion has governed the internal mass transfer.

The variation of the SMER with the drying time is presented in Figure 12. It is defined as the ratio of the moisture evaporated from wet product to the energy input to the drying system and it was calculated using Eq. (5). The SMER was in the range of $0.122-1.308 \mathrm{~kg} / \mathrm{kW}$ h, with an average of $0.562 \mathrm{~kg} / \mathrm{kW}$ h. Figure 12 also shows the variation of the SEC, STEC, and SEEC with the drying time. The SEC is the ratio of the total energy input (thermal energy + electrical energy) to the drying system to the moisture evaporated from wet material, the STEC is the ratio of the thermal energy input to the drying system to the moisture evaporated from wet material, the SEEC is the ratio of the electrical energy input to the drying system to the moisture evaporated from wet material, and these were calculated using Eqs. (2)-(4), respectively. The SEC ranged between 0.806 and $8.657 \mathrm{~kW} \mathrm{h/kg}$, with an average of $4.119 \mathrm{~kW} \mathrm{~h} /$ $\mathrm{kg}$, while the STEC and SEEC ranged between 0.385 and $4.136 \mathrm{~kW} \mathrm{~h} / \mathrm{kg}$ and 0.421 and $4.521 \mathrm{~kW} \mathrm{h/kg}$, respectively, with corresponding average values of 1.968 and $2.151 \mathrm{~kW}$ $\mathrm{h} / \mathrm{kg}$. As seen from Figure 12, the SMER decreased with increasing in drying time, while the SEC, STEC, and SEEC increased with increasing in drying time, and these is due to the decreased the moisture removal rate with increasing in drying time.

The inflow, outflow, and loss of exergy for the drying section during the drying experiment versus the drying time are presented in Figure 13, and these were calculated using Eqs. (13)-(15), respectively. These three parameters were found to be over $1439.42-1959.34 \mathrm{~W}, 249.24-398.17 \mathrm{~W}$, and 1154.94-1630.24 W, respectively, with corresponding average values of $1708.32,330.08$, and $1378.24 \mathrm{~W}$.

The thermal dryer and exergy efficiencies of the PSBARMFD versus the drying time are presented in Figure 14. The thermal efficiency of the drying system is the ratio of the energy used for moisture evaporation to the energy input to the drying system, the exergy efficiency is the ratio of exergy use in the drying of the product to exergy of the drying air supplied to the drying chamber, and these were 
TABLE 5: Equations used to determine the production cost, profit, payback period, and net present value of the PSBA-RMFD.

\begin{tabular}{lccc}
\hline Economic parameter & Equation & Eq. no. & Ref. \\
\hline Production cost & $C_{\mathrm{Pr}}=C_{\mathrm{fm}}+C_{\mathrm{ec}}+C_{\mathrm{lb}}+C_{\mathrm{ad}}$ & $(21)$ & $(22)$ \\
Energy consumption cost & $C_{\mathrm{ec}}=C_{\mathrm{el}}+C_{\mathrm{bmf}}$ & $(23)$ \\
Additional cost & $C_{\mathrm{ad}}=C_{m}+C_{\mathrm{dp}}$ & $(24)$ \\
Profit & $\mathrm{PR}=\mathrm{TS}-I_{C}-C_{\mathrm{Pr}}$ & $(25)$ \\
Return of capital & $\mathrm{ROC}=\mathrm{PR} / I_{C}$ & $(26)$ \\
Payback period & $\mathrm{PP}=I_{C} / \mathrm{PR}$ & $(27)$ \\
Net present value & $\mathrm{NPV}=\sum_{n-1}^{N} P_{n}(1+i)^{n}-I_{C}$ & {$[54]$} \\
Discounted present value $(S)$ & $P_{n}=S(1+i)^{-n}$ & {$[54]$} \\
\hline
\end{tabular}

TABle 6: Uncertainties of parameters during the paddy drying experiment.

\begin{tabular}{lcc}
\hline Parameter & Unit & $\begin{array}{c}\text { Uncertainty } \\
\text { range }\end{array}$ \\
\hline Time measurement & Min & \pm 0.1 \\
Air temperature & ${ }^{\circ} \mathrm{C}$ & \pm 0.20 \\
Paddy temperature & ${ }^{\circ} \mathrm{C}$ & \pm 0.20 \\
Relative humidity & $\%$ & \pm 0.346 \\
Paddy moisture content change & $\%$ (wet basis) & \pm 0.51 \\
Mass of paddy & $\mathrm{kg}$ & \pm 0.14 \\
Mass of coconut shell charcoal & $\mathrm{kg}$ & \pm 0.11 \\
Air velocity & $\mathrm{m} / \mathrm{s}$ & \pm 0.24 \\
\hline
\end{tabular}

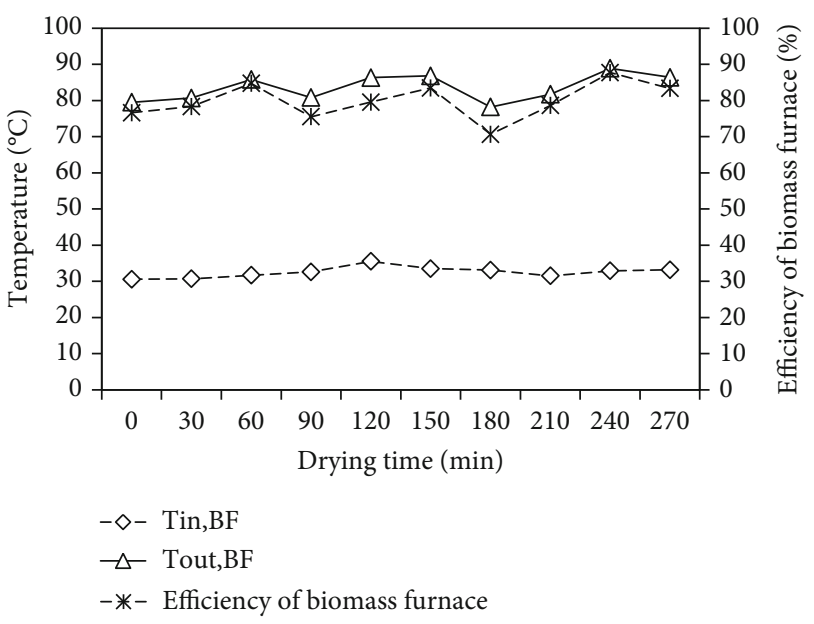

FIGURE 7: Variation of efficiency of biomass furnace and inlet and outlet temperatures of the biomass furnace with drying time.

calculated using Eqs. (12) and (16), respectively. The thermal efficiency varied from $7.82 \%$ to $83.99 \%$, with an average of $36.105 \%$, while the exergy efficiency ranged from $15.28 \%$ to $25.64 \%$, with an average of $19.46 \%$. As shown in Figure 14, the thermal dryer and exergy efficiencies were found to be high at the beginning of the drying process and low at the end of the drying process. The high values of the thermal dryer and exergy efficiencies at the beginning of the drying process due to rapid evaporation of the surface moisture of the paddy or the drying rate is very high and vice versa. Furthermore, they decreases exponentially during the drying from inside the paddy until the end of the drying process. Figure 14 also shows the improvement potential of the dryer with the drying time and it was calculated using Eq. (17), which was in the range of 858.90-1355.62 W, with an average of $1114 \mathrm{~W}$. A summary of the performance evaluation of the PSBA-RMFD is presented in Table 7.

3.2. Evaluation of the Effect of Drying Air Temperature on the Quality of Drying Products. In the drying process, beside performance of drying system and drying time, the quality of drying product must be taken into consideration, and the quality of drying product is greatly influenced by drying air temperature. The drying air temperature may cause the quality degradation of the drying product. In the paddy drying process, the quality of the drying product can be expressed in terms of color of paddy grains and percentages of head rice yield, broken rice, rice grouts, and rice of whitewash. The percentages of head rice, broken rice, rice grouts and rice of whitewash obtained by milling the paddy. In PSBA-RMFD, the paddy grains is dried with a drying air temperature of $75.40-81.40^{\circ} \mathrm{C}$, and the moisture content of the paddy grains in the dryer is reduced from $20.90 \%$ wet basis to $13.30 \%$ wet basis in 270 minutes. The values of head rice yield, broken rice, rice grouts and rice of whitewash were $67.37 \pm 0.69 \%, 26.34 \pm 0.80 \%, 3.55 \pm 0.51 \%$, and $2.72 \pm 0.75 \%$, respectively. Based on the Indonesian national rice quality standard (SNI No.01-6128-2015) as shown in Table 8, the quality of rice obtained by drying paddy grains using the PSBA-RMFD at a drying air temperature of $75.40-81.40^{\circ} \mathrm{C}$ is belong to in the third medium class. It can be stated that the quality of rice is low or there is a decrease in the quality of paddy during drying process due to the low percentage of head rice yield and high percentages of broken rice, rice groats, and rice of whitewash.

The color of the paddy grain samples after successive drying time intervals is shown in Figure 15. From the figure, it can be seen that the color of the paddy grain sample during the drying process at a drying air temperature of 75.40$81.40^{\circ} \mathrm{C}$ changed significantly. This is due to the high drying 


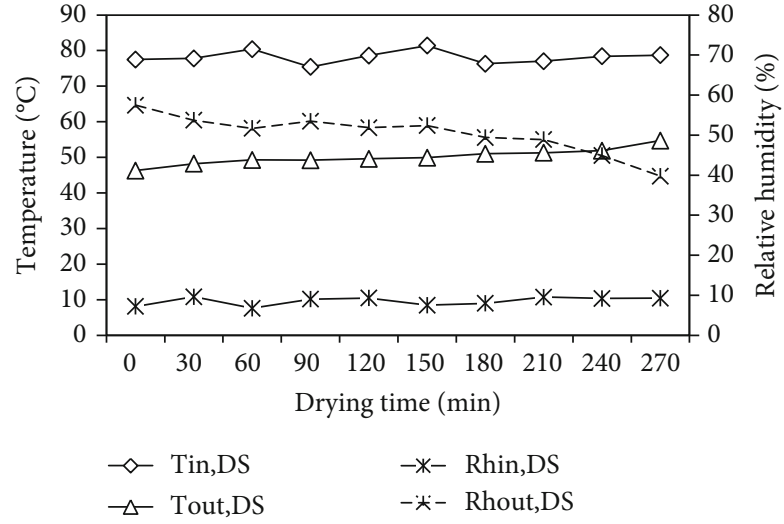

FIGURE 8: Variation of temperatures and relative humidity at the inlet and outlet of the drying section with drying time.

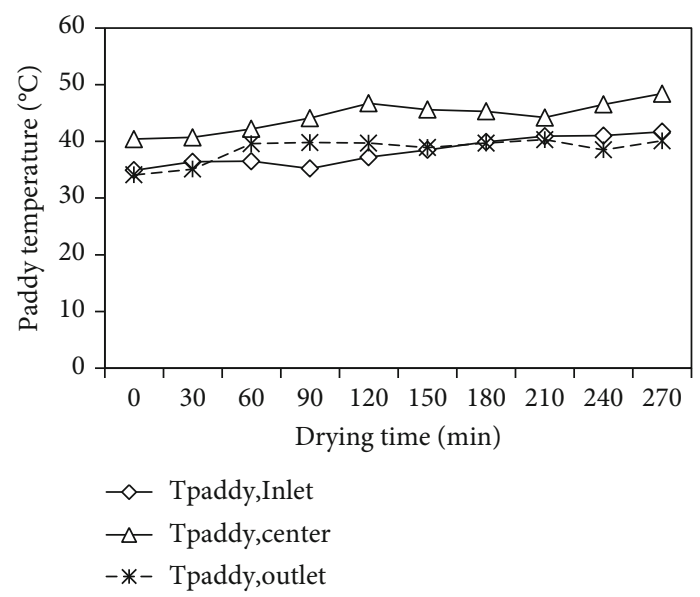

FIGURE 9: Variation of paddy temperatures at the inlet, center, and outlet of the drying section with drying time.

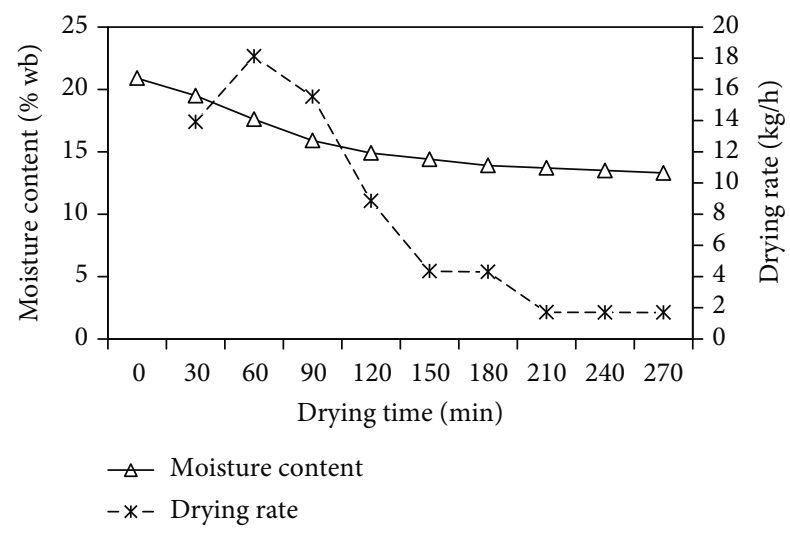

Figure 10: Variation of moisture content and drying rate with drying time.

air temperature and longer drying time to achieve a paddy moisture content of around $13.3 \%$.

3.3. Economic Evaluation. An economic analysis was performed for the PSBA-RFMD to calculate the PP and NPV,

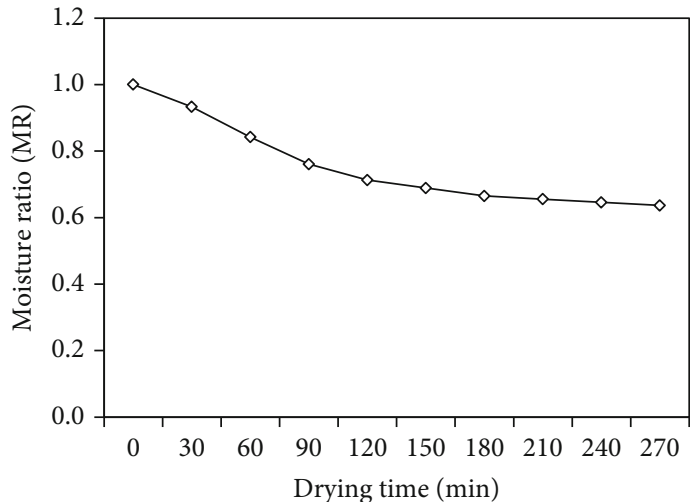

FIGURE 11: Variation of moisture ratio (MR) with drying time.

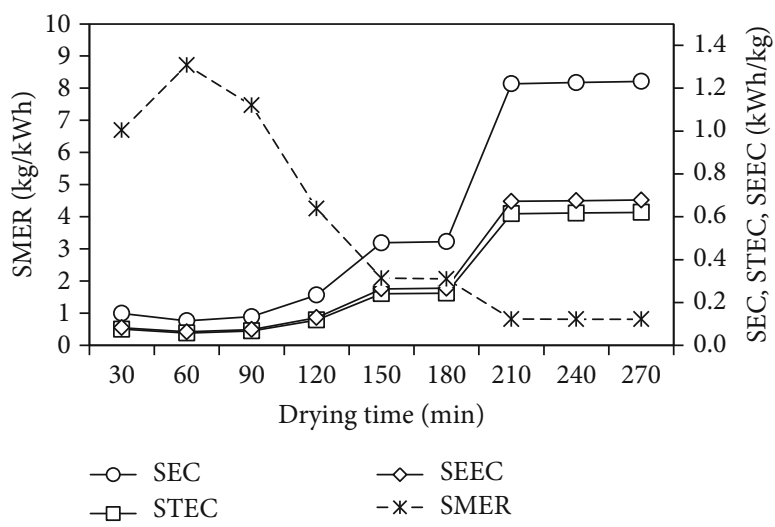

FIgURE 12: Variation of SMER, SEC, STEC, and SEEC with drying time.

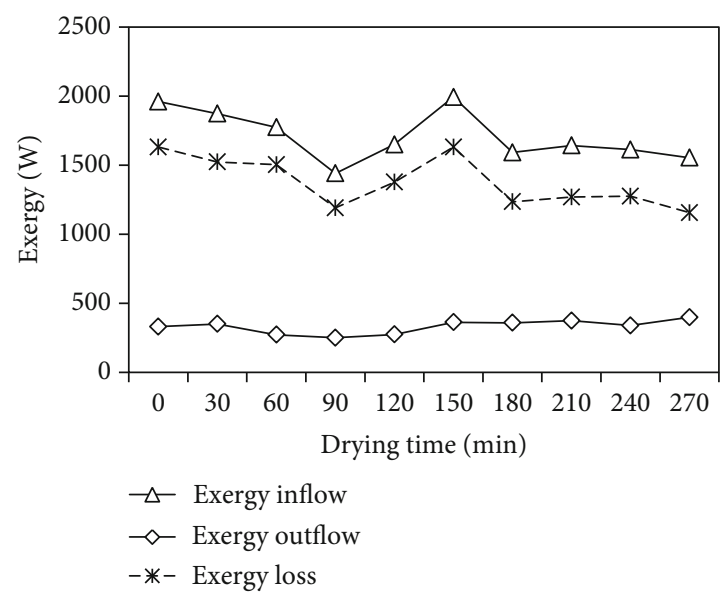

FIGURE 13: Variation of exergies with drying time.

which are strongly determined by $I_{C}, C_{\mathrm{pr}}$, total sale of the dried product, and PR. $I_{C}$ of the PSBA-RMFD included the costs of buying the construction material and equipment and the labor cost for the construction and installation. The 


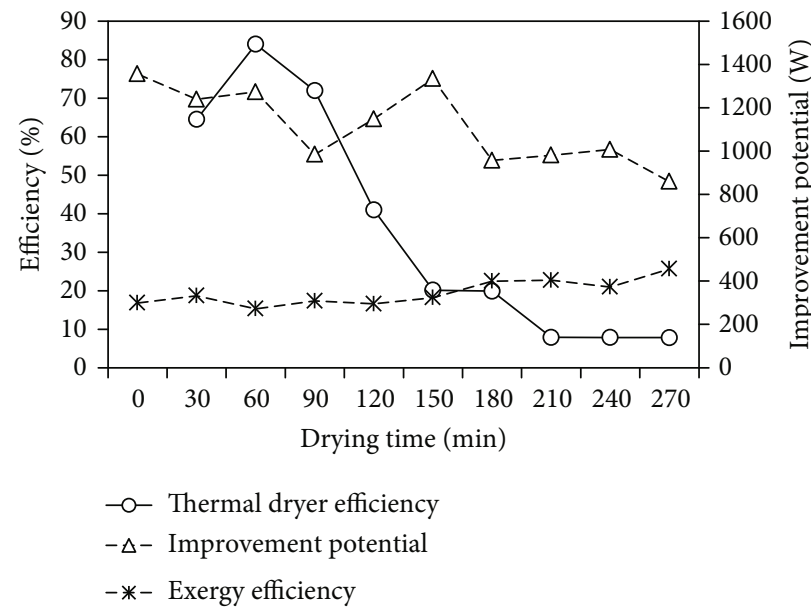

FIgURE 14: Variation of efficiencies and improvement potential with drying time.

TABLe 7: Performance evaluation of the PSBA-RMFD.

\begin{tabular}{lcc}
\hline Parameter & Unit & Value \\
\hline Initial moisture content (wet basis) & $\%$ & 20.90 \\
Final moisture content (wet basis) & $\%$ & 13.30 \\
Average drying air temperature & ${ }^{\circ} \mathrm{C}$ & 78.15 \\
Average drying air relative humidity & $\%$ & 8.55 \\
Drying time & $\mathrm{Min}$ & 270 \\
Average SMER & $\mathrm{kg} / \mathrm{kW}$ & 0.56 \\
& $\mathrm{~h}$ & \\
Average SEC & $\mathrm{kW} \mathrm{h} /$ & 4.119 \\
& $\mathrm{~kg}$ & \\
Average STEC & $\mathrm{kW} \mathrm{h/}$ & 1.968 \\
& $\mathrm{~kg}$ & \\
Average SEEC & $\mathrm{kW} \mathrm{h} /$ & 2.151 \\
Average thermal efficiency of the PSBA-RMFD & $\mathrm{kg}$ & 36.17 \\
Average exergy efficiency & $\%$ & 19.46 \\
Average improvement potential & $\mathrm{W}$ & 1114 \\
Average efficiency of biomass furnace & $\%$ & 79.53 \\
Percentage of biomass energy used in the PSBA- & $\%$ & 47.77 \\
RMFD & \multicolumn{2}{c}{} \\
\hline
\end{tabular}

components of $I_{C}$ of the PSBA-RFMD are listed in Table 4. The annual $C_{\mathrm{pr}}$ (drying cost) was classified into direct and fixed costs. The direct costs included the cost of buying the fresh paddy, labor cost, electricity cost, and biomass fuel cost; these costs were found to be $110288.87,5036.02$, 2337.77, and 1208.64 USD/year, respectively. The fixed costs included the maintenance cost and depreciation, and these were found to be 76.94 and 346.23 USD/year, respectively. Then, the annual $C_{\mathrm{pr}}$ (drying cost) was found to be 119294.47 USD/year. On the contrary, the annual PR and the $I_{C}$ were 2003.34 and $3846.95 \mathrm{USD}$, respectively. Therefore, PP and NPV were found to be approximately 1.9 years and 7472.34 USD, respectively. A summary of the economic evaluation of the PSBA-RMFD is presented in Table 9.
TABLE 8: Indonesian national rice quality standard (SNI No.016128-2015) [58].

\begin{tabular}{|c|c|c|c|c|c|}
\hline \multirow{3}{*}{ No. } & \multirow{3}{*}{ Quality components } & \multicolumn{4}{|c|}{ Quality class } \\
\hline & & \multirow{2}{*}{ Premium } & \multicolumn{3}{|c|}{ Medium } \\
\hline & & & 1 & 2 & 3 \\
\hline 1 & Level of polishing $(\%, \mathrm{~min})$ & 100 & 95 & 90 & 80 \\
\hline 2 & Moisture content $(\%, \max )$ & 14 & 14 & 14 & 15 \\
\hline 3 & Head rice $(\%, \min )$ & 95 & 78 & 73 & 60 \\
\hline 4 & Broken $(\%, \max )$ & 5 & 20 & 25 & 35 \\
\hline 5 & Grain grouts $(\%, \max )$ & 0 & 2 & 2 & 5 \\
\hline 6 & Red grain $(\%, \max )$ & 0 & 2 & 3 & 3 \\
\hline 7 & Yellow/damaged grain $(\%, \max )$ & 0 & 2 & 3 & 5 \\
\hline 8 & Grain of whitewash $(\%, \max )$ & 0 & 2 & 3 & 5 \\
\hline 9 & Foreign object $(\%, \max )$ & 0 & 0.02 & 0.05 & 0.2 \\
\hline 10 & Grains (grains/100 g, max & 0 & 1 & 2 & 3 \\
\hline
\end{tabular}

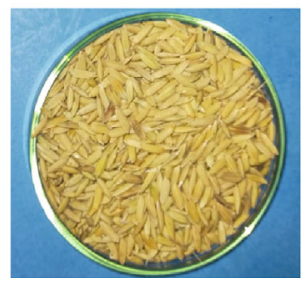

After 180 minutes

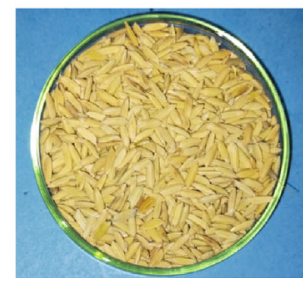

After 270 minutes
FIGURE 15: Color of the paddy grain samples after successive drying time intervals. 
TABLE 9: Economic evaluation of PSBA-RMFD.

\begin{tabular}{|c|c|c|}
\hline Parameter & Unit & Value \\
\hline Investment cost (initial cost) $\left(I_{C}\right)$ & USD & $3,846.95$ \\
\hline Initial weight of paddy & $\mathrm{kg}$ & 400 \\
\hline Final weight of paddy & $\mathrm{kg}$ & 364 \\
\hline Price of fresh paddy & $\mathrm{USD} / \mathrm{kg}$ & 0.385 \\
\hline Price of dried paddy & $\mathrm{USD} / \mathrm{kg}$ & 0.462 \\
\hline Price of coconut shell charcoal & $\mathrm{USD} / \mathrm{kg}$ & 0.105 \\
\hline Price of electricity & $\mathrm{USD} / \mathrm{kW} \mathrm{h}$ & 0.095 \\
\hline Labor charge & USD/day & 6.99 \\
\hline Discount factor & $\%$ & 12 \\
\hline Cost of maintenance & $\%$ & 2 \\
\hline Depreciation & $\%$ & 10 \\
\hline Life of the PSBA-RMFD & Year & 10 \\
\hline Annual production cost $\left(C_{\mathrm{pr}}\right)$ & USD/year & $119,294.47$ \\
\hline Annual total sale of dried product (revenue) & USD/year & $121,297.82$ \\
\hline Annual profit & USD/year & $2,003.34$ \\
\hline Payback period (PP) & Year & 1.9 \\
\hline Net present value (NPV) & USD & $7,472.34$ \\
\hline
\end{tabular}

\section{Conclusions}

A PSBA-RMFD with a drying capacity of $400 \mathrm{~kg} / \mathrm{h}$ was tested and evaluated for its performance. The results showed that the PSBA-RMFD reduced the paddy moisture content from $20.90 \%$ (wet basis) to $13.30 \%$ (wet basis) in $270 \mathrm{~min}$, with an average temperature of $78.15^{\circ} \mathrm{C}$ and average relative humidity of $8.55 \%$. The SEC varied in the range of $0.806-$ $8.657 \mathrm{~kW} \mathrm{h/kg}$ of water evaporated, with an average of $4.119 \mathrm{~kW} \mathrm{~h} / \mathrm{kg}$ of water evaporated. The values of the STEC and SEEC varied from 0.385 to $4.136 \mathrm{~kW} \mathrm{h/kg}$ and 0.421 to $4.521 \mathrm{~kW} \mathrm{h/kg}$ of water evaporated, respectively, with respective averages of 1.968 and $2.151 \mathrm{~kW} \mathrm{h/kg} \mathrm{of} \mathrm{water}$ evaporated. The SMER was in the range of $0.122-1.308 \mathrm{~kg}$ of water evaporated $/ \mathrm{kW} \mathrm{h}$, with an average of $0.562 \mathrm{~kg} / \mathrm{kW}$ $\mathrm{h}$. The values of the thermal dryer and exergy efficiencies were in the range of $7.82 \%-83.99 \%$ and $15.28 \%-25.64 \%$, respectively, with corresponding averages of $36.11 \%$ and $19.46 \%$.The IP was in the range of $858.90-1355.62 \mathrm{~W}$, with an average of $1114 \mathrm{~W}$. The efficiency of the biomass furnace varied between $70.63 \%$ and $87.70 \%$, with an average of $79.53 \%$. The PP achieved by the PSBA-RMFD was 1.9 years. The percentage of biomass energy used in this drying system was approximately $47.77 \%$ of the overall energy. In addition, the heat energy required for heating the drying air during the drying process was supplied only by the biomass fuel. However, the quality of paddy grains was changes significantly during drying process.

\section{Nomenclature}

$\begin{array}{ll}C_{\mathrm{ad}}: & \text { Additional cost } \\ C_{\mathrm{bmf}}: & \text { Biomass fuel cost } \\ C_{\mathrm{dp}}: & \text { Depreciation cost }\end{array}$

\begin{tabular}{|c|c|}
\hline$C_{\text {ec }}:$ & Energy consumption cost \\
\hline$C_{\mathrm{el}}:$ & Electricity cost \\
\hline$C_{\mathrm{fm}}:$ & Fresh material cost \\
\hline$C_{\mathrm{lb}}:$ & Labor cost \\
\hline$C_{m}:$ & Maintenance cost \\
\hline$C_{\mathrm{Pa}}:$ & Air specific heat $\left(\mathrm{Jkg}^{-1} \mathrm{C}^{-1}\right)$ \\
\hline$C_{\mathrm{Pr}}:$ & Production cost \\
\hline $\mathrm{CV}_{\text {bmf }}:$ & Biomass fuel caloric value (kcal/kg) \\
\hline $\cos \phi:$ & Power factor \\
\hline$E_{\mathrm{Bbf}}:$ & $\begin{array}{l}\text { Electrical energy required by the biomass } \\
\text { furnace blower }(\mathrm{W})\end{array}$ \\
\hline$E_{\mathrm{bmf}}:$ & $\begin{array}{l}\text { Heat energy produced from burning of the } \\
\text { biomass fuel (W) }\end{array}$ \\
\hline$E_{\text {Bmfd }}:$ & $\begin{array}{l}\text { Electrical energy required by the mixed } \\
\text { flow dryer blower }(\mathrm{W})\end{array}$ \\
\hline$E_{\mathrm{Mbe}}:$ & $\begin{array}{l}\text { Electrical energy required by the bucket } \\
\text { elevator motor }(\mathrm{W})\end{array}$ \\
\hline$E_{\mathrm{Mdr}}:$ & $\begin{array}{l}\text { Electrical energy required by the discharge } \\
\text { roller motor (W) }\end{array}$ \\
\hline$E_{\mathrm{Mvf}}:$ & $\begin{array}{l}\text { Electrical energy required by the vibratory } \\
\text { feeder motor }(\mathrm{W})\end{array}$ \\
\hline$H_{\mathrm{fg}}:$ & $\begin{array}{l}\text { Latent heat of vaporization of water }(\mathrm{kJ} / \\
\mathrm{kg})\end{array}$ \\
\hline$I:$ & Current (A) \\
\hline$\dot{m}_{a}:$ & Mass flow rate of air $(\mathrm{kg} / \mathrm{s})$ \\
\hline$\dot{m}_{\mathrm{bmf}}:$ & Consumption rate of biomass fuel $(\mathrm{kg} / \mathrm{h})$ \\
\hline$m_{\text {bonedrypd }}:$ & Mass of bone dry of paddy (kg) \\
\hline$M_{\mathrm{Cdb}, t}:$ & $\begin{array}{l}\text { Paddy moisture content (dry basis) at the } \\
\text { time " } t \text { " }\end{array}$ \\
\hline$M_{\mathrm{Cdb}, t+\Delta \mathrm{t}}:$ & $\begin{array}{l}\text { Paddy moisture content (dry basis) at the } \\
\text { time " } t+\Delta t "\end{array}$ \\
\hline$M_{o}:$ & Initial paddy moisture content (\%) \\
\hline$M_{t}:$ & Instantaneous paddy moisture content (\%) \\
\hline$\dot{m}_{\text {water }}:$ & Drying rate $(\mathrm{kg} / \mathrm{h})$ \\
\hline
\end{tabular}




\begin{tabular}{|c|c|}
\hline$m_{\text {wetpd }}:$ & Mass of wet of paddy $(\mathrm{kg})$ \\
\hline $\mathrm{Rh}_{\mathrm{amb}}$ : & Ambient relative humidity (\%) \\
\hline $\mathrm{Rh}_{i, \mathrm{ds} \text { and }} \mathrm{Rh}_{o, \mathrm{ds}}:$ & $\begin{array}{l}\text { Relative humidity entering and leaving the } \\
\text { drying section, respectively (\%) }\end{array}$ \\
\hline $\mathrm{T} 1_{=} T_{\mathrm{amb}(\mathrm{db})}:$ & Dry bulk ambient temperature $\left({ }^{\circ} \mathrm{C}\right)$ \\
\hline $\mathrm{T} 2=T_{\mathrm{amb}(\mathrm{wb})}:$ & Wet bulk ambient temperature $\left({ }^{\circ} \mathrm{C}\right)$ \\
\hline $\mathrm{T} 3=T_{\mathrm{ai}, \mathrm{bf}}:$ & $\begin{array}{l}\text { Air temperature at the inlet of the biomass } \\
\text { furnace (dry bulk) }\left({ }^{\circ} \mathrm{C}\right)\end{array}$ \\
\hline $\mathrm{T} 4=T_{\mathrm{ao}, \mathrm{bf}}:$ & $\begin{array}{l}\text { Air temperature at the outlet of the bio- } \\
\text { mass furnace (dry bulk) }\left({ }^{\circ} \mathrm{C}\right)\end{array}$ \\
\hline $\mathrm{T} 5=T_{\mathrm{ai}, \mathrm{ds}(\mathrm{db})}:$ & $\begin{array}{l}\text { Temperature of dry bulk air entering the } \\
\text { drying section }\left({ }^{\circ} \mathrm{C}\right)\end{array}$ \\
\hline T6 $=T_{\text {ai,ds }(w b)}:$ & $\begin{array}{l}\text { Temperature of wet bulk air entering the } \\
\text { drying section }\left({ }^{\circ} \mathrm{C}\right)\end{array}$ \\
\hline $\mathrm{T} 7=T_{\text {pdi,ds }}:$ & $\begin{array}{l}\text { Paddy temperature at the inlet of the dry- } \\
\text { ing section }\left({ }^{\circ} \mathrm{C}\right)\end{array}$ \\
\hline $\mathrm{T} 8_{=} T_{\mathrm{pdc}, \mathrm{ds}}:$ & $\begin{array}{l}\text { Paddy temperature at the center of the } \\
\text { drying section }\left({ }^{\circ} \mathrm{C}\right)\end{array}$ \\
\hline $\mathrm{T} 9=T_{\text {pdo,ds }}:$ & $\begin{array}{l}\text { Paddy temperature at the outlet of the } \\
\text { drying section }\left({ }^{\circ} \mathrm{C}\right)\end{array}$ \\
\hline$T_{10=} T_{\mathrm{ao}, \mathrm{ds}(\mathrm{db})}:$ & $\begin{array}{l}\text { Dry bulk air temperature at the outlet of } \\
\text { the drying section }\left({ }^{\circ} \mathrm{C}\right)\end{array}$ \\
\hline$T_{11=} T_{\mathrm{ao}, \mathrm{ds}(\mathrm{wb})}:$ & $\begin{array}{l}\text { Wet bulk air temperature at the outlet of } \\
\text { the drying section }\left({ }^{\circ} \mathrm{C}\right)\end{array}$ \\
\hline$V:$ & Voltage (V) \\
\hline$\Delta t:$ & Interval of drying time $(\mathrm{h})$. \\
\hline
\end{tabular}

\section{Data Availability}

The data from drying experiment can be access at the following link: https://drive.google.com/file/d/ 1pgSOLhNxs63UI785y-gMhXwg6Oe_a_vF/view?usp= sharing. And also the data from drying experiment is already in the manuscript and can be seen in Table 3.

\section{Additional Points}

Highlights. (i) A pilot-scale biomass-assisted recirculating mixed-flow drying system for drying paddy (PSBA-RMFD) was tested. (ii) The average specific energy consumption (SEC), specific thermal energy consumption (STEC), and specific thermal energy consumption (SEEC) were 4.119, 1.968 , and $2.151 \mathrm{~kW} \mathrm{h/kg}$ of water evaporated, respectively. (iii) The average thermal dryer efficiency was $36.11 \%$. (iv) The average exergy efficiency and payback period of the dryer were $19.46 \%$ and 1.9 years, respectively. (v) The heat energy required in the drying process was supplied only by biomass energy

\section{Conflicts of Interest}

The authors declare that they have no conflicts of interest.

\section{Acknowledgments}

The authors would like to thank the Indonesian Ministry of Education and Culture, Research, and Technology for funding this research under a Penelitian Terapan Unggulan Per- guruan Tinggi (PTUPT) research grant scheme (No. 010/ 27.O10.5/PN/VII/2021).

\section{References}

[1] BPS, Badan Pusat Statistik Indonesia, Statistik Indonesia, Jakarta, 2019.

[2] C. Bonazzi, F. Courteis, C. Geneste, M. C. Lahon, and J. Bimbent, "Influence of drying conditions on the processing quality of rough rice," Drying Technology, vol. 51, no. 3, pp. 1141-1157, 1997.

[3] D. B. Brooker, F. W. Bakker-Arkema, and C. W. Hall, Drying and Storage of Grains and Oilseeds, Van Nostrand Reinhold, New York, 1992.

[4] D. C. Wang and Y. C. Lee, "Performance evaluation of reversible air flow drying in circulating dryer," International Journal of Advances in Chemical Engineering and Biological Sciences, vol. 4, no. 1, pp. 185-190, 2017.

[5] F. Weigler, H. Scaar, G. Franke, and J. Mellmann, "Development of a novel mixed flow dryer design," Hungarian Agricultural Engineering, no. 27, pp. 46-50, 2015.

[6] T. Oksanen, "Controlling air flow in recirculating mixed flow batch dryer with double bed mode," Computers and Electronics in Agriculture, vol. 149, pp. 133-138, 2018.

[7] F. Weigler and J. Mellmann, "Investigation of grain mass flow in a mixed flow dryer," Particuology, vol. 12, pp. 33-39, 2014.

[8] M. J. Tiusanen, H. T. Jokiniemi, and M. I. Hautala, "Grain dryer temperature optimisation with simulation and a test dryer," in 4th IFAC Conference on Modelling and Control in Agriculture, Espoo, Finland, August 2013.

[9] I. Keppler, L. Kocsis, I. Oldal, I. Farkas, and A. Csatar, "Grain velocity distribution in a mixed flow dryer," Advanced Powder Technology, vol. 23, no. 6, pp. 824-832, 2012.

[10] J. Mellmann, K. L. Iroba, T. Metzger, E. Tsotsas, C. Meszaros, and I. Farkas, "Moisture content and residence time distributions in mixed-flow grain dryers," Biosystems Engineering, vol. 109, no. 4, pp. 297-307, 2011.

[11] L. Kocsis, T. Teodorov, J. Mellmann, K. Gottschalk, C. S. Mészáros, and I. Farkas, "Analysis of grain mass flow experiments in a mixed flow dryer," in Proceedings of the 17th World Congress The International Federation of Automatic Control Seoul, Korea, July 2008.

[12] G. Stanescu and M. R. Errera, "Optimization of continuous mixed-flow grain dryers by constructal theory," International Journal of Heat and Technology, vol. 34, Supplement 1, pp. S151-S160, 2016.

[13] O. A. Khatchatourian, H. A. Vielmo, and L. A. Bortolaia, "Modelling and simulation of cross flow grain dryers," Biosystems Engineering, vol. 116, no. 4, pp. 335-345, 2013.

[14] H. T. Jokiniemi and J. M. Ahokas, "Drying process optimisation in a mixed-flow batch grain dryer," Biosystems Engineering, vol. 121, pp. 209-220, 2014.

[15] C. W. Cao, D. Y. Yang, and Q. Liu, "Research on modeling and simulation of Mixed Flow grain dryer," Drying Technology, vol. 25, no. 4, pp. 681-687, 2007.

[16] V. Turanjanin, V. Bakic, M. Jovanovic, and M. Pezo, "Fossil fuels substitution by the solar energy utilization for the hot water production in the heating plant "Cerak" in Belgrade," International Journal of Hydrogen Energy, vol. 34, no. 16, pp. 7075-7080, 2009. 
[17] M. Yahya, A. Fudholi, and K. Sopian, "Energy and exergy analyses of solar-assisted fluidized bed drying integrated with biomass furnace," Renewable Energy, vol. 105, pp. 22-29, 2017.

[18] M. Yahya, H. Fahmi, S. Hadi, and Edison, "Performance analyses on fluidized bed dryer integrated biomass furnace with and without air preheater for paddy drying," International Journal of Power Electronics and Drive System, vol. 10, no. 3, pp. 1555-1563, 2019.

[19] M. C. Ndukwu, M. Simo-Tagne, F. I. Abam, O. S. Onwuka, and L. Bennamoun, "Exergetic sustainability and economic analysis of hybrid solar-biomass dryer integrated with copper tubing as heat exchanger," Heliyon, vol. 6, no. 2, article e03401, 2020.

[20] A. Bosomtwe, J. K. Danso, E. A. Osekre, G. P. Opit, and J. O. Akowuah, "Effectiveness of the solar biomass hybrid dryer for drying and disinfestation of maize," Journal of Stored Products Research, vol. 83, pp. 66-72, 2019.

[21] E. Tarigan, "Mathematical modeling and simulation of a solar agricultural dryer with back- up biomass burner and thermal storage," Case Studies in Thermal Engineering, vol. 12, pp. 149-165, 2018.

[22] M. Yahya, "Design and performance evaluation of a solar assisted heat pump dryer integrated with biomass furnace for red chilli," International Journal of Photoenergy, vol. 2016, Article ID 8763947, 14 pages, 2016.

[23] S. Sonthikun, P. Chairat, K. Fardsin, P. Kirirat, A. Kumar, and P. Tekasakul, "Computational fluid dynamic analysis of innovative design of solar-biomass hybrid dryer: an experimental validation," Renewable Energy, vol. 92, pp. 185-191, 2016.

[24] S. Dhanushkodi, V. H. Wilson, and K. Sudhakar, "Life cycle cost of solar biomass hybrid dryer systems for cashew drying of nuts in India," Environmental and Climate Technologies, vol. 15, no. 1, pp. 22-33, 2015.

[25] Y. M. Yunus, H. H. Al-Kayiem, and K. A. K. Albaharin, "Design of a biomass burner/gas-to-gas heat exchanger for thermal backup of a solar dryer," Journal of Applied Sciences, vol. 11, no. 11, pp. 1929-1936, 2011.

[26] M. A. Leon and S. Kumar, "Design and performance evaluation of a solar-assisted biomass drying system with thermal storage," Drying Technology, vol. 26, no. 7, pp. 936-947, 2008.

[27] A. Madhlopa and G. Ngwalo, "Solar dryer with thermal storage and biomass-backup heater," Solar Energy, vol. 81, no. 4, pp. 449-462, 2007.

[28] J. Prasad and V. K. Vijay, "Experimental studies on drying of Zingiber officinale, Curcuma longa l. and Tinospora cordifolia in solar-biomass hybrid drier," Renewable Energy, vol. 30, no. 14, pp. 2097-2109, 2005.

[29] T. A. R. Hamdani, T. A. Rizal, and Z. Muhammad, "Fabrication and testing of hybrid solar-biomass dryer for drying fish," Case Studies in Thermal Engineering, vol. 12, pp. 489-496, 2018.

[30] F. A. Neba and Y. J. Nono, "Modeling and simulated design: a novel model and software of a solar-biomass hybrid dryer," Computers \& Chemical Engineering, vol. 1042, pp. 128-140, 2017.

[31] M. A. Billiris and T. J. Siebenmorgen, "Energy use and efficiency of rice-drying systems II. Commercial, cross-flow dryer measurements," Applied Engineering in Agriculture, vol. 30, no. 2, pp. 217-226, 2014.

[32] H. R. Gazor and M. R. Alizadeh, "Comparison of rotary dryer with conventional fixed bed dryer for paddy drying, milling quality and energy consumption," Agricultural Engineering International: The CIGR e-journal, vol. 22, no. 2, pp. 264$271,2020$.

[33] M. Tohidi, M. Sadeghi, and M. Torki-Harchegani, "Energy and quality aspects for fixed deep bed drying of paddy," Renewable and Sustainable Energy Reviews, vol. 70, pp. 519528, 2017.

[34] M. S. H. Sarker, M. N. Ibrahim, N. Ab Aziz, and P. Mohd Salleh, "Energy and rice quality aspects during drying of freshly harvested paddy with industrial inclined bed dryer," Energy Conversion and Management, vol. 77, pp. 389-395, 2014.

[35] M. Yapa, Design and testing of pilot continuous fluidized bed paddy dryer, M. Eng thesis, King Mongkut's University of Technology Thonburi, Bangkok, Thailand, 1994.

[36] S. Soponronnarit, M. Yapha, and S. Prachayawarakorn, "Cross-flow fluidized bed paddy dryer: prototype and commercialization," Drying Technology, vol. 13, no. 8-9, pp. 2207-2216, 1995.

[37] S. Soponronnarit, P. Rordprapat, and S. Wetchacama, "Mobile fluidized bed paddy dryer," Drying Technology, vol. 16, no. 7, pp. 1501-1513, 1998.

[38] S. Prachayawarakorn, N. Poomsa-ad, and S. Soponronnarit, "Quality maintenance and economy with high-temperature paddy-drying processes," Journal of Stored Products Research, vol. 41, no. 3, pp. 333-351, 2005.

[39] W. Jittanit, N. Saeteaw, and A. Charoenchaisri, "Industrial paddy drying and energy saving options," Journal of Stored Products Research, vol. 46, no. 4, pp. 209-213, 2010.

[40] W. Jittanit, G. Srzednicki, and R. H. Driscoll, "Comparison between fluidized bed and spouted bed drying for seeds," Drying Technology, vol. 31, no. 1, pp. 52-56, 2013.

[41] M. N. Ibrahim, M. S. H. Sarker, N. Ab Aziz, and P. M. Salleh, "Drying performances and milling quality of rice during industrial fluidized bed drying of paddy in Malaysia," Pertanika Journal of Science and Technology, vol. 23, no. 2, pp. 297-309, 2015.

[42] R. J. Pontawe, R. C. Martinez, N. T. Asuncion, and R. B. Villacorte, "Development of a fully-automated pilot-scale model fluidized bed drying system for complete drying of paddy," Asian Journal of Applied Sciences, vol. 3, no. 6, pp. 747-758, 2015.

[43] S. Mehran, M. Nikian, M. Ghazi, H. Zareiforoush, and I. Bagheri, "Experimental investigation and energy analysis of a solar-assisted fluidized- bed dryer including solar water heater and solar-powered infrared lamp for paddy grains drying," Solar Energy, vol. 190, pp. 167-184, 2019.

[44] T. Madhiyanon, S. Soponronnarit, and W. Tia, "Continuous drying of paddy in two-dimensional spouted bed," Kasetsart Journal (Natural Science), vol. 34, pp. 308-314, 2000.

[45] S. Hemhirun and P. Bunyawanichakul, "Cross-flow paddy dryer application using infrared gas burner," International Journal of Advanced Research in Engineering and Technology, vol. 11, no. 6, pp. 204-214, 2020.

[46] S. Hemhirun and P. Bunyawanichakul, "Effect of the initial moisture content of the paddy drying operation for the small community," Journal of Agricultural Engineering, LI, vol. 51, no. 3, pp. 176-183, 2020.

[47] M. H. T. Mondal, K. S. P. Shiplu, K. P. Sen, J. Roy, and M. S. H. Sarker, "Performance evaluation of small scale energy efficient mixed flow dryer for drying of high moisture paddy," Drying Technology, vol. 37, no. 12, pp. 1541-1550, 2019. 
[48] P. P. Thant, K. C. C. Thin, and T. Nwe, "Economic investigation of a re-circulating grain dryer," International Journal of Scientific Engineering and Technology Research, vol. 8, pp. 540-544, 2019.

[49] S. Firouzi, M. R. Alizadeh, and D. Haghtalab, "Energy consumption and rice milling quality upon drying paddy with a newly- designed horizontal rotary dryer," Energy, vol. 119, pp. 629-636, 2017.

[50] C. Nimmol and S. Devahastin, "Evaluation of performance and energy consumption of an impinging stream dryer for paddy," Applied Thermal Engineering, vol. 30, no. 14-15, pp. 2204-2212, 2010.

[51] C. Nimmol, K. Sathapornprasath, and S. Devahastin, "Drying of high-moisture paddy using a combined impinging stream and pneumatic drying system," Drying Technology, vol. 30, no. 16, pp. 1854-1862, 2012.

[52] B. Prastowo, "Biomass resource in Indonesia: Indonesia's solid biomass energy potential," in Presented in Indonesia-German Workshop and Seminar, pp. 1-15, Institute Technology of Bandung, 2011.

[53] E. K. Akpinar, "Drying of mint leaves in a solar dryer and under open sun: Modelling, performance analyses," Energy Conversion and Management, vol. 51, no. 12, pp. 2407-2418, 2010.

[54] M. Yahya, H. Fahmi, A. Fudholi, and K. Sopian, "Performance and economic analyses on solar-assisted heat pump fluidised bed dryer integrated with biomass furnace for rice drying," Solar Energy, vol. 174, pp. 1058-1067, 2018.

[55] M. Yahya, R. Hasibuan, R. Sundari, and K. Sopian, "Experimental investigation of the performance of a solar dryer integrated with solid desiccant coloums using water based solar collector for medicinal herb," International Journal of Power Electronics and Drive System, vol. 12, no. 2, pp. 1024-1033, 2021.

[56] S. Janjai, P. Intawee, J. Kaewkiew, C. Sritus, and V. Khamvongsa, "A large-scale solar greenhouse dryer using polycarbonate cover: Modeling and testing in a tropical environment of Lao People's Democratic Republic," Renewable Energy, vol. 36, no. 3, pp. 1053-1062, 2011.

[57] A. Fudholi, K. Sopian, M. Gabbasa et al., "Techno-economic of solar drying systems with water based solar collectors in Malaysia: a review," Renewable and Sustainable Energy Reviews, vol. 51, pp. 809-820, 2015.

[58] Badan Standardisasi Nasional, Standar Nasional Indonesia 6128: 2015. Beras, Jakarta, 2015. 